\title{
DEVELOPING ECONOMIES AND THE ASIA-PACIFIC ECONOMIC COOPERATION FORUM-APEC: INTRABLOC TRADE AND ATTRACTION OF FOREIGN DIRECT INVESTMENT FROM THE REGION
}

\author{
Christian Rodríguez \\ Universidad Peruana de Ciencias Aplicadas \\ cdrodrig@upc.edu.pe
}

\begin{abstract}
Resumen
Considerando que uno de los principales objetivos del APEC es facilitar el comercio internacional y las inversiones entre sus miembros, se dice a menudo que asumir la presidencia del APEC (como el Perú en 2008) contribuirá a promover el comercio y a atraer inversiones de las economías miembros. ¿Pero existe algún patrón que permita cuantificar las ventajas que se obtienen de este compromiso? Luego de analizar las estadísticas comerciales de las economías en desarrollo del APEC desde la creación de este foro en 1989, se puede deducir que asumir la Presidencia no garantiza a la economía en desarrollo un incremento en su comercio con el resto de las economías APEC. Inmediatamente después de haber sido sede del evento, sus importaciones crecen más en comparación con sus exportaciones. En cuanto a la inversión extranjera, no hay información contundente sobre su crecimiento. No obstante, aun cuando el crecimiento del comercio y la atracción de la inversión extranjera directa de otras economías miembros del APEC no dependen exclusivamente de asumir la presidencia del foro, este compromiso constituye una oportunidad única para promover el comercio con el bloque económico más importante del mundo.
\end{abstract}

Palabras clave: comercio internacional, economías miembros, economías en desarrollo, economías APEC, Dirección de Comercio del FMI, inversión extranjera directa, bloque económico.

\section{Abstract}

Since one of the main goals of the APEC is to facilitate the international trade and investments among its members, it is said that taking over APEC presidency (as Peru in 2008), will contribute to foster trade and attract investments from member economies. But, is there any pattern which allows quantifying the benefits resulting from this kind of commitment? After evaluating the trade statistics of APEC developing economies ever since the creation of the Forum in 1989, it can be inferred that presiding APEC does not guarantee an increase in its trade with the rest of APEC economies. Right after hosting the summit, its imports grow higher compared with its exports, but there is not any conclusive information on the growth of foreign direct investment (FDI). Nevertheless, even though the growth of trade and FDI attraction from APEC other member economies does not rely exclusively on taking over the Forum's Presidency, this commitment is a unique opportunity to promote trade with the planet's most important economic bloc.

Key words: international trade, member economies, developing economies, APEC economies, IMF's Direction of Trade, foreign direct investment, economic bloc. 


\section{Introduction}

The privilege of assuming the Presidency of the Asia-Pacific Economic Cooperation Forum (APEC) is both a challenge as well as an opportunity for any of its member economies. Several meetings are held in the host country during its year-long Presidency, which comprise not only a logistical challenge for the institutions that organize them, but also a highly sophisticated level of coordination among public, private and academic organizations. Therefore, the economy ${ }^{1}$ that holds APEC's Presidency assumes a great responsibility on hosting most of the annual meetings, but will also enjoy the enormous opportunity to show its competitive advantages, as a country, to its fellow member economies. Moreover, it must be underscored that two of APEC's main objectives are promoting trade among its members, and fostering investment throughout the region.

Accordingly, when APEC's Presidency is assumed by a developing economy, it must be thoroughly prepared in order to stand up to the challenge and be able to benefit the opportunities that can be foreseen from the meetings, the most important of which are APEC CEO Summit and APEC Economic Leaders' Meeting ${ }^{2}$. Obviously, the organization of these meetings and summits requires a huge effort and investment of all sort of resources, both from the public and private sectors of the host economy, which will yield the generation of new business relationships and the attraction of foreign direct investment (FDI) and

1. In APEC, the term "economy" is preferred to that of "country" in order to designate its members.

2. Chiefs of State's Summit. In APEC, the term "Economic Leader" is preferred to any other designation for a Chief of State from a member economy. tourists from the Asia-Pacific region. These benefits would allow the growth of the host economy as a whole, and also reflect one of the strengths of APEC: the active participation of the private business community in order to foster trade and investment.

To that extent, it's of interest to quantify the impact of organizing such a complex series of meetings on a member economy, especially for those in a developing stage which, proportionally, direct enormous resources to ensure the success of each and every one of these events.

This document intends to analyze the experience of nine developing economies that are APEC members which have had the privilege of assuming its Presidency and therefore have been hosts to most of APEC's annual meetings. The purpose of this analysis is to determine if there is some kind of relation between holding APEC's Presidency and the growth in trade with and FDI attraction from the other member economies. Furthermore, this document also intends to call for the attention on the factors that foster trade and investment in the region in order to deepen the actions that will allow a more accelerated growth pace.

\section{A. Definition of "developing economy"}

In November 15, 1994 at Bogor, Indonesia, the leaders of APEC's economies resolved to establish a set of goals for APEC, which were called the "Bogor Goals". By acknowledging the importance of international trade and investment as means to achieve economic development, APEC's Leaders established as one of the most important goals total liberalization of trade and investment in the Asia-Pacific region by 2020 . However, by also acknowledging the existence of serious differences 
among its members in terms of economic development, the Leaders agreed that developed economies should liberalize trade and investment within the region by 2010 , but developing economies should do so by 2020 . This was reaffirmed in the Osaka Action Agenda (OAA), established in Japan in 1995 , which sets the guidelines to reach the Bogor Goals.

So, in order to appropriately set the scope for this analysis, it is imperative to establish the definition of a developing country or a developing economy. Currently, there is no consensus on what should be deemed as a "developing country". A developed country is often pointed out as a country which reaches some minimal standards on several economic and social indicators; on the other side, a developing country is the one that doesn't reach these standards. According to the United Nations Conference on Trade and Development-UNCTAD Manual of Statistics (2006), within APEC only Australia, Canada, Japan, New Zealand, Japan and the United States should be considered as "developed countries". The same vision is shared by the International Monetary Fund-IMF (2008) which calls these countries "advanced economies", but also clearly establishes a subgroup of "recently industrialized Asian economies" including Hong Kong, South Korea, Singapore and Taiwan. Within APEC Australia, Canada, Japan, New Zealand, Japan and the United States are commonly called developed economies (Chan, 2008), meanwhile the other 16 member economies are called "developing economies". However, in several APEC working papers, Hong Kong, South Korea ${ }^{3}$, Singapore and Taiwan ${ }^{4}$ are considered to have an inter-

3. In APEC, this country is officially called "Republic of Korea".

4. In APEC, Taiwan is officially called Chinese Taipei, a term that will be used hereafter. mediate level of development, therefore being considered as "recently industrialized economies", and thus remaining only 12 member economies which can be truly considered as "developing economies".

The scope of this analysis reaches the experience of those APEC member economies that are considered as truly developing economies which have also assumed the Forum's Presidency; these economies are: Brunei Darussalam, Chile, China, Indonesia, Malaysia, Mexico, Philippines, Thailand and Vietnam. These economies have been selected because both developed economies and recently industrialized economies have a high level of development, register a large capability to finance the organization of APEC's events, and are generally present a higher degree of openness to foreign trade; therefore the impact of assuming APEC's Presidency shouldn't be as important as it could be for a developing economy. Table 1 shows a list of APEC's 21 member economies ordered by the year they entered the Forum; it also shows the year they assumed the Presidency and a classification according to their level of development.

\section{B. Trade and investment as means to foster development: a brief reaffirmation}

There is plenty of literature on the importance of international trade and FDI as means to foster economic growth; therefore, these factors are able to put a country in the path for development. Dollar and Kraay (2001) clearly establish, based on empiric evidence, the direct correlation between the expansion of trade volumes and the rates of economic growth and hence a substantial increase in the income of the inhabitants. Likewise, FDI, as one of the main ways 
Table 1. APEC's member economies, ordered by the year they joined the Forum

\begin{tabular}{|c|c|c|c|c|}
\hline Country & $\begin{array}{l}\text { Year in which } \\
\text { it joined APEC }\end{array}$ & Classification in APEC & $\begin{array}{l}\text { Classification according } \\
\text { to IMF }\end{array}$ & $\begin{array}{l}\text { Year it held APEC's } \\
\text { Presidency }\end{array}$ \\
\hline Australia & 1989 & Developed Economy & Advanced economy & 1989, 2007 \\
\hline Brunei Darussalam & 1989 & Developing Economy & $\begin{array}{l}\text { Emerging and developing } \\
\text { economy }\end{array}$ & 2000 \\
\hline Canada & 1989 & Developed Economy & Advanced economy & 1997 \\
\hline Indonesia & 1989 & Developing Economy & $\begin{array}{l}\text { Emerging and developing } \\
\text { economy }\end{array}$ & 1994 \\
\hline Japan & 1989 & Developed Economy & Advanced economy & 1995 \\
\hline Korea, Republic of & 1989 & Developing Economy & Advanced economy & 1991, 2005 \\
\hline Malaysia & 1989 & Developing Economy & $\begin{array}{l}\text { Emerging and developing } \\
\text { economy }\end{array}$ & 1998 \\
\hline New Zealand & 1989 & Developed Economy & Advanced economy & 1999 \\
\hline Philippines & 1989 & Developing Economy & $\begin{array}{l}\text { Emerging and developing } \\
\text { economy }\end{array}$ & 1996 \\
\hline Singapore & 1989 & Developing Economy & Advanced economy & 1990 \\
\hline Thailand & 1989 & Developing Economy & $\begin{array}{l}\text { Emerging and developing } \\
\text { economy }\end{array}$ & 1992,2003 \\
\hline United States & 1989 & Developed Economy & Advanced economy & 1993 \\
\hline $\begin{array}{l}\text { China, Popular } \\
\text { Republic }\end{array}$ & 1991 & Developing Economy & $\begin{array}{l}\text { Emerging and developing } \\
\text { economy }\end{array}$ & 2001 \\
\hline Hong Kong, China & 1991 & Developing Economy & Advanced economy & - \\
\hline Chinese Taipei & 1991 & Developing Economy & Advanced economy & - \\
\hline Mexico & 1993 & Developing Economy & $\begin{array}{l}\text { Emerging and developing } \\
\text { economy }\end{array}$ & 2002 \\
\hline Papua New Guinea & 1993 & Developing Economy & $\begin{array}{l}\text { Emerging and developing } \\
\text { economy }\end{array}$ & - \\
\hline Chile & 1994 & Developing Economy & $\begin{array}{l}\text { Emerging and developing } \\
\text { economy }\end{array}$ & 2004 \\
\hline Peru & 1998 & Developing Economy & $\begin{array}{l}\text { Emerging and developing } \\
\text { economy }\end{array}$ & 2008 \\
\hline Russia & 1998 & Developing Economy & $\begin{array}{l}\text { Emerging and developing } \\
\text { economy }\end{array}$ & - \\
\hline Vietnam & 1998 & Developing Economy & $\begin{array}{l}\text { Emerging and developing } \\
\text { economy }\end{array}$ & 2006 \\
\hline
\end{tabular}

Source: APEC / World Economic Outlook 2008-IMF.

international capital has to flow (Krugman and Obstfeld, 2006), has the necessary potential to reduce poverty: it's not only capable of generating employment, but also provides additional benefits (spillovers) that facilitate technological transfer, human capital development, and stimulate competition (Goldin and Reinert, 2006). Consequently, it's not surprising that it is often recommended for developing countries to 
open their economies to international trade through a gradual reduction of their tariff and non-tariff barriers (Bhagwati, 2007), in as much as a market liberalization to facilitate FDI (OECD, 1999).

\section{Analysis of trade flows with the Asia-Pacific region}

In this section we will analyze the evolution of trade flows with and from the Asia-Pacific region for each of APEC's developing economies that have assumed the Forum's Presidency. In each case we will the total amount of trade flows from 1989 (the year when APEC was created) to 2007. Furthermore, to determine the growth rate after assuming the Presidency, we will analyze the annual variation of these trade flows. This will allow us to notice if there has been any impact in the trade flows and in the attraction of FDI due to the promotion of a country's competitive advantages during its Presidency. Moreover, this will also allow us to see whether this growth is the result of an existing tendency or it's the consequence of assuming this important commitment.

Nonetheless, we must underscore that trade statistics for each member economy have been considered for the "intrazone" data only from the year an economy has officially entered APEC. Besides, in order to consider the impact of assuming APEC's Presidency on a developing economy, this evaluation will start the very next year in which this economy assumed that commitment, since APEC's annual meetings usually begin by mid-February and finish by the end of November.

Likewise, it's very important to notice that this analysis is only a first indicator on the performance of a country's trade flows with and from the other APEC economies, since it's very difficult to isolate the effect of assuming APEC's Presidency vis-à-vis being an active member of it. Obviously, trade flows can be affected by several variables that go beyond the impact caused by assuming this kind of commitment and the actions it comprises. Among other factors, trade flows can be affected by subscribing a regional trade agreement (RTA), a variation in the terms of trade, a change in the demand patterns with the main trade partners, a unilateral modification of the effective tariff level by a country or its main trade partners, a widespread economic crisis (such as the Asian Crisis of 1998), or a big political or social phenomenon. Even though there are important initiatives to estimate or predict the volume of trade flows, such as the gravity model of trade, it's difficult to find one that actually comprises every single variable.

Having this in mind, the present document doesn't want to explain all the factors that may affect the trade flows of the analyzed economies. Instead, its main objective is to compile the intrazone trade flows for the economies mentioned above and to point out the incidence that the assumption of APEC's Presidency may have. We will also stress the importance that RTA's have in analyzing trade flows and the impact a widespread crisis may have on these developing economies. Now, table 2 shows RTA's in force that involve the analyzed developing economies.

A first approximation to reduce the degree of uncertainty generated over the motives that stimulate trade growth, due to large amount of variables that this implies, consists in taking into account the existence of a RTA between some member econo- 
Table 2. Regional Trade Agreements in force that involve selected developing economies and other APEC economies

\begin{tabular}{|c|c|c|}
\hline Name of the RTA & Countries involved & Date of entry into force \\
\hline $\begin{array}{c}\text { Asia Pacific Trade Agreement (APTA)- } \\
\text { Bangkok Agreement }\end{array}$ & $\begin{array}{l}\text { Bangladesh, China, South Korea, } \\
\text { India, Laos and Sri Lanka }\end{array}$ & $\begin{array}{c}\text { June } 17,1976 \\
\text { (China officially joined APTA in } \\
\text { January } 1,2002 \text { ) }\end{array}$ \\
\hline $\begin{array}{l}\text { Economic Complementation Agreement } \\
\left.\text { N. }{ }^{\circ} 8 \text { (ACE N. }{ }^{\circ} 8\right)\end{array}$ & Mexico and Peru & March 25, 1987 \\
\hline ASEAN Free Trade Agreement (AFTA) & $\begin{array}{c}\text { Brunei Darussalam, Cambodia, } \\
\text { China, Indonesia, Laos, Malaysia, } \\
\text { Myanmar, Philippines, Singapore, } \\
\text { Thailand and Vietnam }\end{array}$ & $\begin{array}{c}\text { January } 28,1992 \\
\text { (China established a Free Trade } \\
\text { Area with ASEAN officially in } \\
\text { July } 1,2003 \text { ) }\end{array}$ \\
\hline $\begin{array}{l}\text { North American Free Trade Agreement } \\
\text { (NAFTA) }\end{array}$ & Canada, United States and Mexico & January 1, 1994 \\
\hline Free Trade Agreement & Canada and Chile & July 5, 1997 \\
\hline $\begin{array}{c}\text { Economic Complementation Agreement } \\
\left.\text { N. }{ }^{\circ} 38 \text { (ACE N. }{ }^{\circ} 38\right)\end{array}$ & Chile and Peru & July 1, 1998 \\
\hline $\begin{array}{l}\text { Economic Complementation Agreement } \\
\text { N. }{ }^{\circ} 41 \text { (ACE N. }{ }^{\circ} 41 \text { )-Free Trade Agreement }\end{array}$ & Chile and Mexico & August 1, 1999 \\
\hline Free Trade Agreement & China and Hong Kong & January 1, 2004 \\
\hline Free Trade Agreement & Chile and United States & January 1, 2004 \\
\hline Free Trade Agreement & Chile and South Korea & April 1, 2004 \\
\hline Free Trade Agreement & Australia and Thailand & January 1, 2005 \\
\hline Free Trade Agreement & Japan and Mexico & April 1, 2005 \\
\hline Free Trade Agreement & New Zealand and Thailand & July 1, 2005 \\
\hline $\begin{array}{c}\text { Trans-Pacific Economic Partnership } \\
\text { Agreement (P4) }\end{array}$ & $\begin{array}{l}\text { Brunei Darussalam, Chile, New } \\
\text { Zealand and Singapore }\end{array}$ & May 28, 2006 \\
\hline Free Trade Agreement & Japan and Malaysia & July 13,2006 \\
\hline Free Trade Agreement & Chile and China & October 1, 2006 \\
\hline Free Trade Agreement & Chile and Japan & September 3, 2007 \\
\hline Free Trade Agreement & Japan and Thailand & November 1, 2007 \\
\hline
\end{tabular}

Source: WTO / LAIA / UNESCAP.

mies, since this event usually enhances trade flows. Nevertheless, it's the RTA's between developed economies (or between those with a high development level) and developing economies ${ }^{5}$, which have a bigger impact on trade flows, generate more economic gains and, simultaneously, cre-

5. This kind of agreement is usually known as "North-South". ate positive collateral effects or spillovers (Schiff and Winters, 2003). In fact, as we will show in the analysis of some of APEC's developing economies, the biggest influence ("distortion") on trade flow patterns is caused by the entry into force of this kind of agreements. Nevertheless, we can't generalize or establish an average impact of a North-South RTA; Soloaga and Winters (2001) cite several examples of the high variability of the impact generated by this kind of agreement. 


\subsection{Brunei Darussalam}

Brunei Darussalam is the economy that registers the least trade amount with the Asia-Pacific region and has assumed APEC's Presidency. In addition, Brunei Darussalam was the first developing economy in APEC to be granted with that privilege. Chart 1 shows an irregular growth in Brunei Darussalam's trade flow during the last decade of the past century; it's noticeably the steep fall in the intrazone trade during 1998 due to the Asian Crisis ${ }^{6}$. However, after the crisis, Brunei showed an important recovery, reaching its higher export amounts ever, even though its imports didn't recovery that much.
The main destination of Brunei's exports during the analyzed period is Japan, which represents, in average, $49 \%$ of the annual intrazone exports. After the Asian Crisis, other intrazone destinations such as Indonesia, South Korea and Australia have risen their share as Brunei's customers. On the other hand, Brunei's imports have Singapore as the main intrazone supplier, averaging $35 \%$ annually, followed by Malaysia.

When analyzing the impact for Brunei Darussalam of being APEC's host, chart 1 shows that there is significant growth registered in exports as well as in imports since the second year after assuming

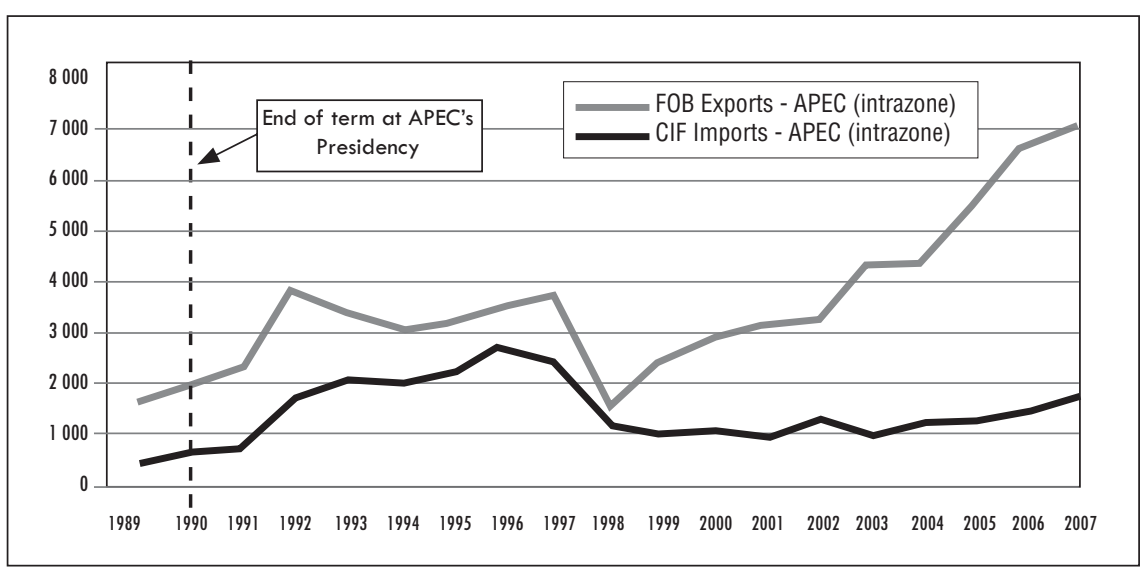

Source: IMF-DOT / Ministry of Finance of Taiwan / Trade Map.

Chart 1

Brunei Darussalam - Evolution of intrazone trade (1989-2007)

(In Millions of USD)

6. According to Parodi (2001), the Asian Crisis, which began in the second half of 1997, had as their main "victims" those Asian economies that, having registered an accelerated economic growth rate in the previous years, suddenly suffered a "brusque contraction in their GDP growth rates". Therefore, the economies that suffered the most were South Korea, Philippines, Indonesia, Malaysia and Thailand. This, however, didn't prevent other countries around the world to be also "infected", in different degrees, due to the effects of this crisis. So, small Asian economies such as Brunei Darussalam, were particularly vulnerable to this negative externalities. 
APEC's Presidency (1992). Nonetheless, growth is only sustained in imports. Chart 2 shows that intrazone trade growth in 1992 came also with a strong extrazone trade increase, but it must be underscored that extrazone trade amounts were minimal, and that explains such great growth rates. It's also important to note that by the time of the Asian Crisis of 1998, Brunei looked for shelter in the extrazone markets to then retake trade with the Asia-Pacific region once the crisis was over.

Finally, it's also important to point out that the RTA's that Brunei has subscribed with APEC countries (AFTA and P4), haven't been a significant influence on its exports, but on its imports. Yet, the variation of both exports and imports has been very irregular during the analyzed period.

\subsection{Chile}

Without a doubt, the country that has shown the biggest dynamism when it comes to subscribing RTA's is Chile; moreover, it has registered one of the highest growth rates on trade in APEC. Chart 3 clearly shows the way in which Chile's trade with the rest of APEC's economies has increased since Chile joined the Forum in 1994 and presented growth rates around $40 \%$ for imports as well as for exports during 2005.

Chile began a very active policy on subscribing RTA's with the region since 1997, when did so with Canada; 10 years later, Chile has signed 8 agreements with 10 fellow member economies. However, during the period between 1995 and 2003, Chile didn't show a significant growth on

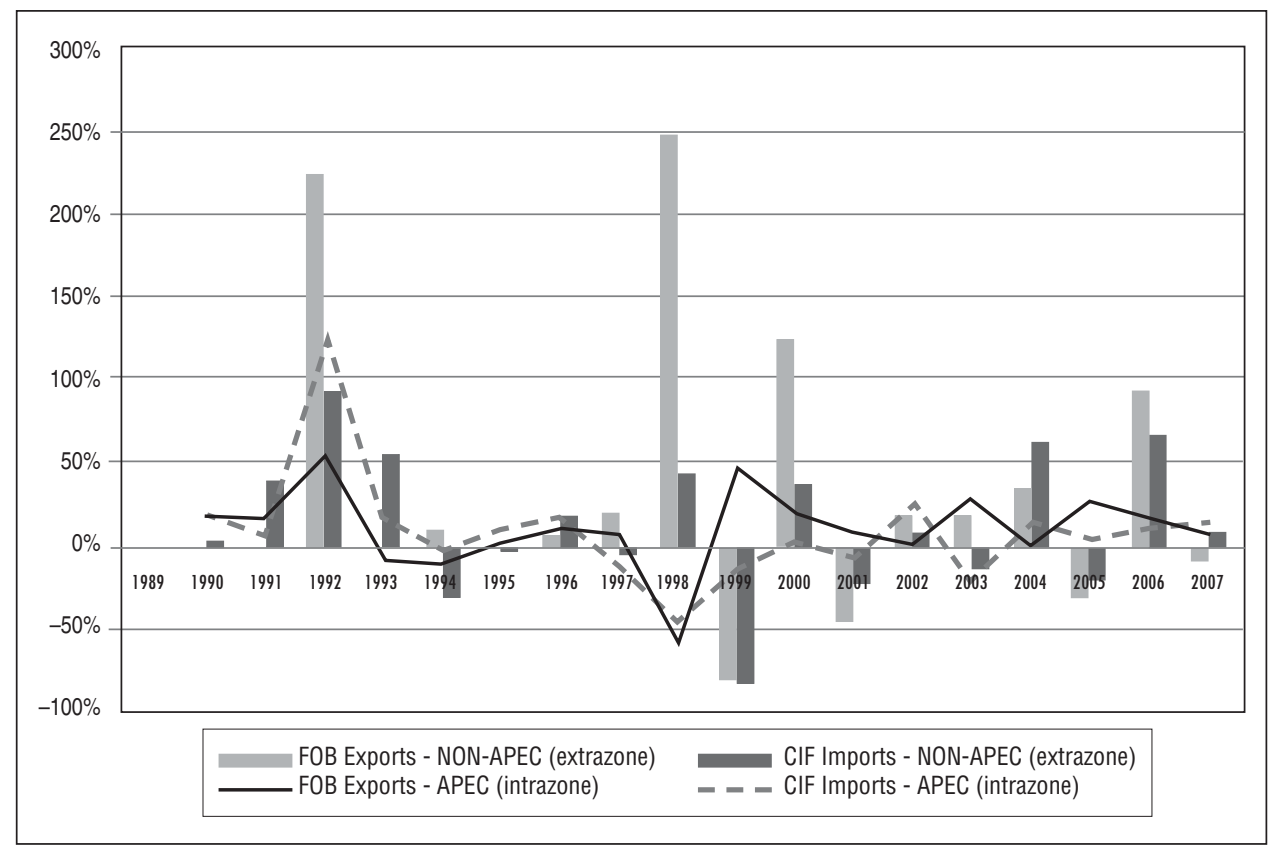

Source: IMF-DOT / Ministry of Finance of Taiwan / Trade Map.

Chart 2

Brunei Darussalam - Annual variation of intra and extrazone trade (1990-2007)

(As a percentage) 


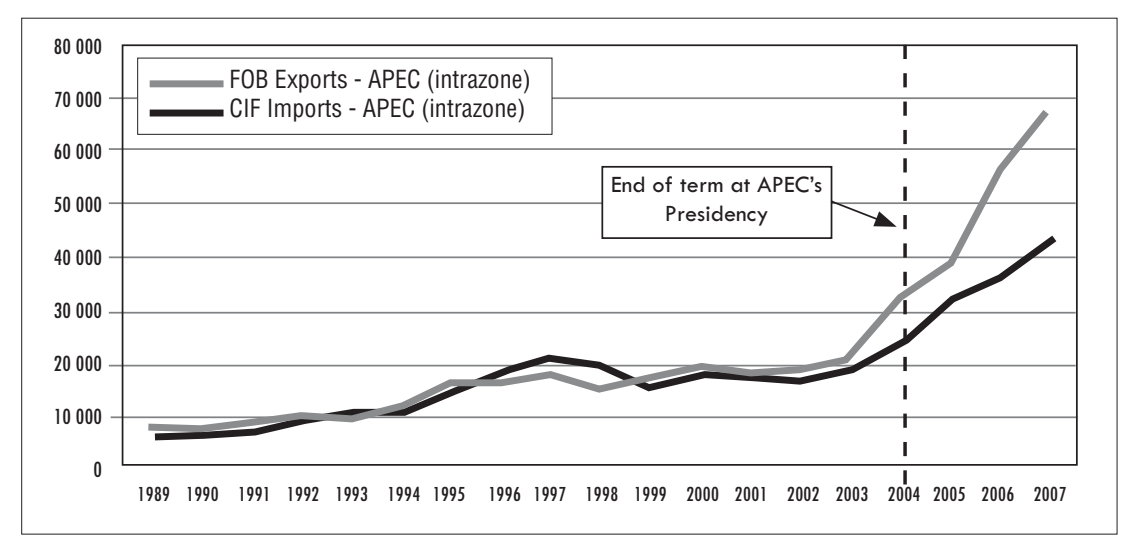

Source: IMF-DOT / Ministry of Finance of Taiwan / Trade Map.

Chart 3

Chile - Evolution of intrazone trade (1989-2007)

(In Millions of USD)

its intrazone exports and even presented a slight decrease on its intrazone imports. It wasn't until 2004 that Chilean foreign trade registered an impressive increase on its trade flows with the region, reaching an annual rate as high as $56 \%$. Even though a large part of this growth can be explained by the entry into force of the Chile-USA Free Trade Agreement (FTA), it must be underscored that there was also a large increase in the Chilean trade with Japan, China, Chinese Taipei and Korea, the last of which had in time its own FTA that entered into force by the second trimester of 2004.

Additionally, 2004 was also an important year for Chile, because during that time, Chile hosted all of APEC's annual meetings. After 2004, Chilean exports continued to rise, not only to developed countries, but also to its fellow LatinAmerican member economies (Mexico and Peru), which can be explained on a previously signed RTA's. In fact, the most notorious increase in intrazone exports was due to China, a country with which Chile signed a FTA that entered into force by the last trimester of 2006. During 2007, the momentum of Chilean exports to China represented $26,6 \%$ of Chile's export to all other APEC's economies, surpassing United States as their first destination, not only in APEC but also in the world.

When it comes to evaluate the performance of Chilean intrazone imports, we notice that they didn't register an increase as noticeable as Chilean intrazone exports. In this kind of trade flow, United States is Chile's main supplier both from APEC and globally. Thus, United States represented, in average, $45 \%$ of Chilean intrazone imports for the analyzed time period, but even though the traded amounts keep on rising year after year, its share on Chilean imports keeps decreasing due to China's participation, which now represents over $25 \%$ of intrazone imports (it was virtually non-existent by 1990).

When evaluating variation tendencies for the Chilean intrazone trade (see chart 4 ), we can notice that, generally 


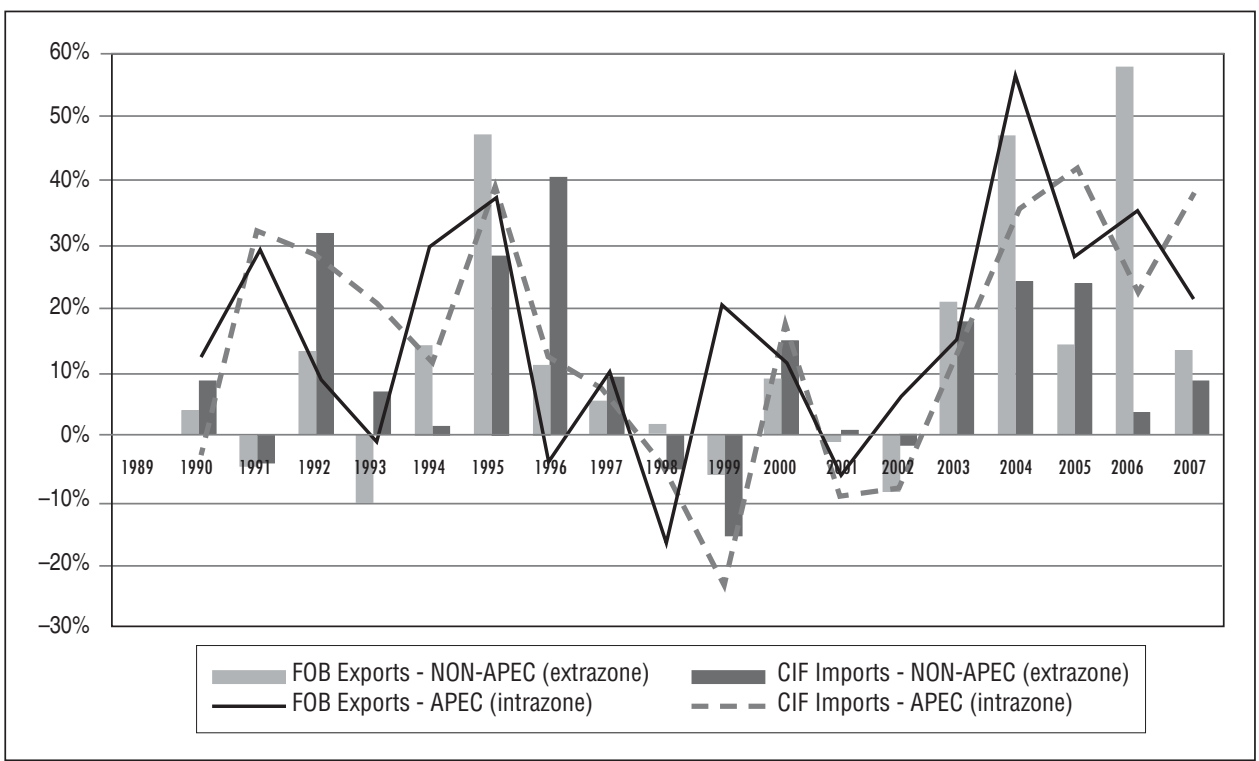

Source: IMF-DOT / Ministry of Finance of Taiwan / Trade Map / ProChile.

\section{Chart 4}

Chile - Annual variation of intra and extrazone trade (1990-2007) (As a percentage)

speaking, these were similar to extrazone trade. We can also note how the excellent performance registered in 1995 couldn't be repeated in the following years, even registering a negative growth in intrazone trade of over $20 \%$ during 1998 due to the Asian Crisis, a situation that continued only for the imports for the next year.

Likewise, we can appreciate that Chile registered important growth rates on trade (intra and extrazone) since 2002. After assuming APEC's Presidency in 2004 though, Chile couldn't duplicate the impressive growth rates in exports of 2004 (56\%), but managed an interesting growth rates over $20 \%$ for the following years, which is a natural deceleration due to bigger trading amounts. On the other hand, we could think that being host of APEC meant for Chile an excellent opportunity to foster importing businesses with the Asia-Pacific region, vis-à-vis the growth rate of $42 \%$ registered the next year.

\subsection{People's Republic of China}

It's no secret that China's trade has registered a spectacular development during the past two decades. This impressive growth has made possible for China go from representing $1,7 \%$ of all the planet's exports in 1989 (USD 59 billions) to comprising 8,9\% in 2007 (USD 1,2 trillions) and thus getting the second place in the ranking of exporting countries after Germany and demoting the United States off the second place for the first time ever (WTO, 2008). This has been possible thanks to an annual average growth of over $19,5 \%$ in its exports during the last 20 years. 
Chart 5 shows the evolution of China's trade with the other APEC's economies and clearly states that ever since China joined the Forum in 1991, its intrazone trade surged. Exports grew at a faster pace than imports the next 10 years, with United States, Hong Kong and Japan collecting the biggest shares of Chinese exports during this time period. Nonetheless, Chinese trade actually registered an even faster growth pace afterwards, specifically since 2001 when China officially joined the World Trade Organization-WTO (December 11, 2001). So, by 2002 Chinese trade surged, both in exports as in imports. Even when in 2002 China began to receive tariff preferences in South Korea thanks to the APTA (see table 2), which meant a $25 \%$ increase in Chinese exports to this country compared to 2001, during this new phase United States, Hong Kong and Japan kept being China's main trade destinations, comprising over two thirds of intrazone exports each year.
When it comes to China's imports, they also take into account Japan, South Korea and United States as the main partners. It's interesting to notice that South Korea surpassed United States as China's second supplier in 2002, when tariff preferences entered into force because of APTA. The main difference between the growth of Chinese imports and that of exports is that the latter are more diversified. China's main suppliers are, inter alia, Chinese Taipei (an economy with which China didn't registered any trade until 1990), Malaysia and Australia.

So, just as China became one of the world's top exporters in only a few years, this country has also become one of the world's main importers, grabbing the third place in the ranking in 2007 , only alter United States and Germany (WTO, 2008), comprising $6,5 \%$ of the world's imports. This was also encouraged by the entry into force of AFTA (see table 2), which

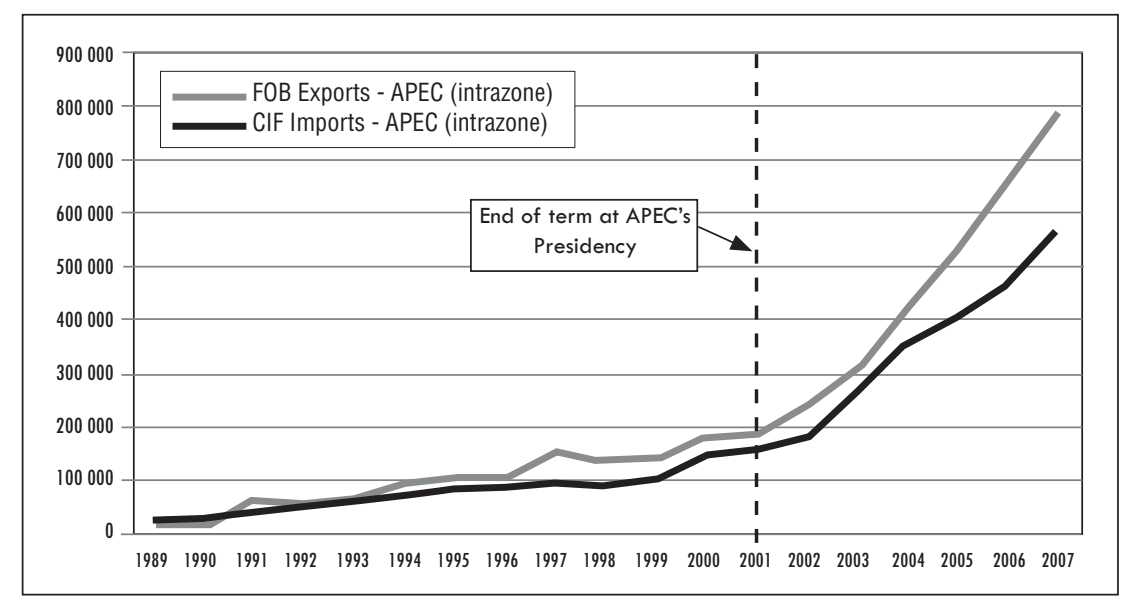

Source: IMF-DOT / Ministry of Finance of Taiwan / Trade Map.

Chart 5

China - Evolution of intrazone trade (1989-2007)

(In Millions of USD) 


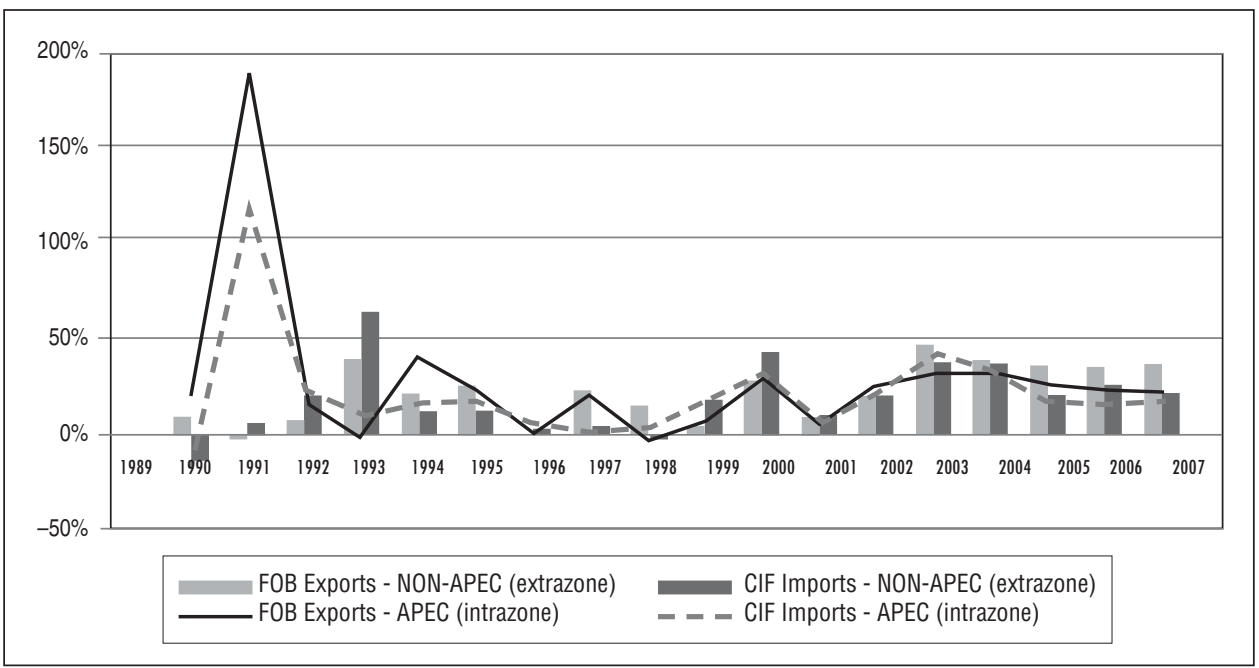

Source: IMF-DOT / Ministry of Finance of Taiwan / Trade Map.

Chart 6

China - Annual variation of intra and extrazone trade (1990-2007) (As a percentage)

allowed several Asian economies to export to China with preferential tariffs starting on the second half of 2003. Likewise, the FTA signed between China and Hong Kong fostered imports from the latter, even though the impact of this agreement wasn't the same for Chinese exports to the island, since Hong Kong doesn't present tariff protections at all.

When comparing the annual variation of China's intra and extrazone trade, chart 6 shows us the impressive growth in the intrazone trade once China joined APEC in 1991. After a natural deceleration, trade growth rates seemed to be very irregular, both in the intra and the extrazone until 2001. After that year, the growth of Chinese trade with the intra and extrazone registered high and sustained rates.

When looking to the data that indicates similar growth patters for the APEC zone as well as for the rest of the world after China assumed the Forum's Presidency, it's valid to ask ourselves whether these patterns reflect a dynamism resulting from the organization of such events or are part of a larger and generalized trend that denotes a stronger participation of China in world trade since it joined the WTO. Rumbaugh and Blancher (2004) mentioned that even though China introduced a series of economic and trade reforms 15 years in advance to its accession to the WTO in 2001, undoubtedly the commitments China assumed since its accession (especially those regarding the reduction of tariff and non-tariff barriers), actually fostered and overall dynamism for world trade.

\subsection{Philippines}

According to chart 7, Philippines has shown in the last 18 years a significant and sustained growth in its trade with the other 


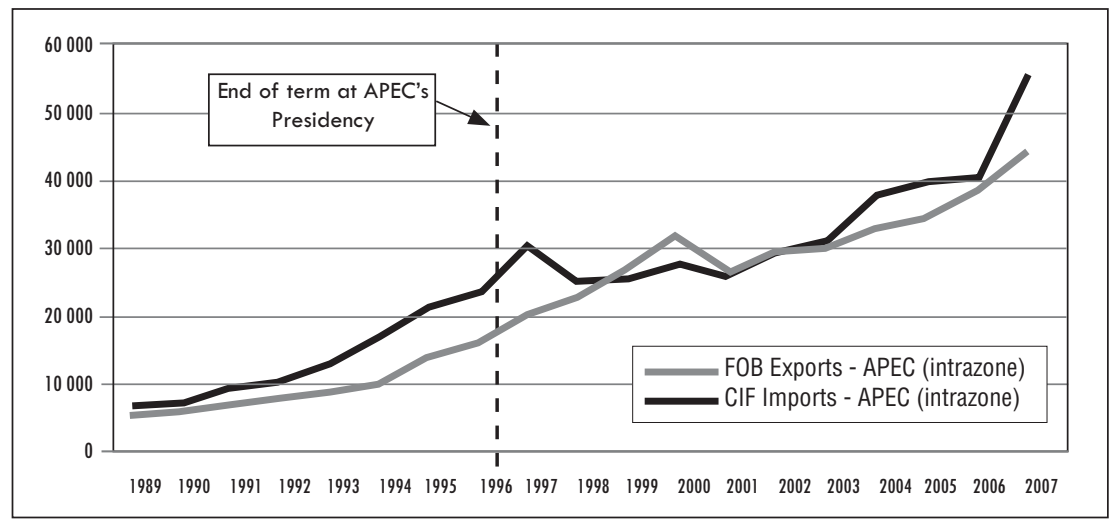

Source: IMF-DOT / Ministry of Finance of Taiwan / Trade Map / Philippines National Statistics Bureau.

Chart 7

Philippines - Evolution of intrazone trade (1989-2007)

(In Millions of USD)

APEC economies; in fact, APEC represents about $80 \%$ of the Philippines total trade flows. However, in contrast to the previous cases, Philippines registers an almost sustained deficit trade balance with the intrazone and the extrazone.

On the same chart we can notice that both exports and imports registered an increase after Philippines assumed APEC's Presidency in 1996. Accordingly, in 1997 there was a notorious growth on imports; meanwhile exports experienced a slight acceleration on the trend they were already registering. But when the Asian Crisis of 1998 appeared, imports sharply decreased, even though exports kept on growing. This is particularly noticeable, since the Asian Crisis actually affected most of the region's exports that year.

Regarding Philippines trade Partners within APEC, United States stands out, but its "weigh" as an export destination in the intrazone has somewhat decreased over time. Thus, from representing over half of the Philippines intrazone exports in 1989,
United States now only comprises less than a quarter of these exports in 2007. Traditionally the second trading partner, Japan explains over $20 \%$ of the intrazone exports. It's also noticeably the rising of several new destinations for Filipino exports, such as China, Hong Kong and Singapore, which are grabbing a bigger share of the Philippines trade flows. The case of China as an export destination is remarkable, since Filipino exports to this country surged when China joined AFTA in 2003, even though the very same trading bloc didn't represent a dramatic increase in Philippines' exports to the rest of the countries of that bloc (even though it existed since 1992).

On the other side, Philippines' imports from the rest of APEC's fellow members actually represent a very dynamic feature for this country's trading flows. In this case, however, the same countries that act as buyers of Filipino goods are also this country's main suppliers: United States and Japan are both the main trading partners, without a clear leadership during the time period analyzed; they both represent over $50 \%$ 


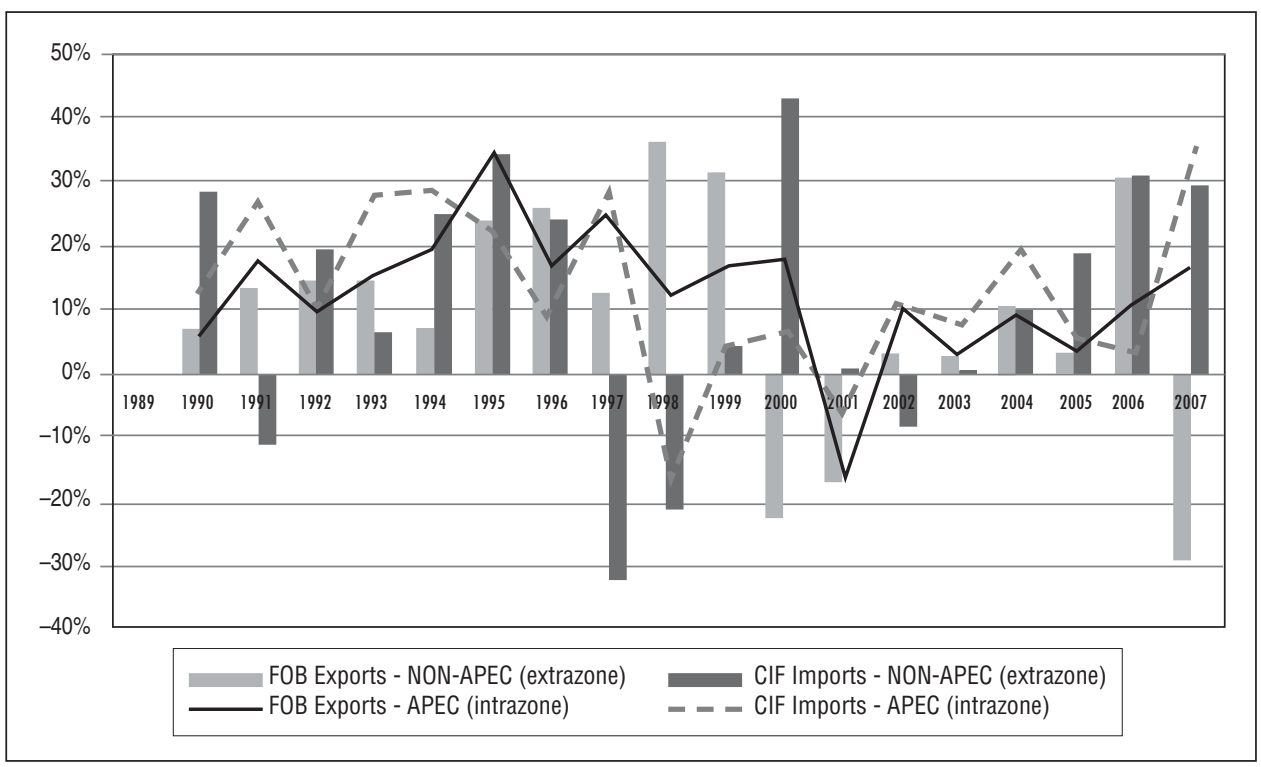

Source: IMF-DOT / Ministry of Finance of Taiwan / Trade Map / Philippines National Statistics Bureau.

\section{Chart 8}

Philippines - Annual variation of intra and extrazone trade (1990-2007) (As a percentage)

of Philippines' intrazone imports. Once again, China, Hong Kong and Singapore are rising as the Philippines' new suppliers, with South Korea approaching to this new group.

When it comes to analyze the variation of intra and extrazone trade, chart 8 shows that Philippines, contrary to other developing economies in APEC, registers more stable growth rates. It's important to notice that the variation tendency for the Philippines's trade with the intrazone is similar to that of the extrazone. Nonetheless, this fact doesn't apply to 1997; a year after Philippines assumed APEC's Presidency, since we can notice that business was diverted to the region from the extrazone, especially imports. In addition, we can notice a variation in the intrazone exports due to the "China effect" originated when this big country joined AFTA in 2003.

\subsection{Indonesia}

Indonesia, just like the other developing economies, has presented a significant increase in its trade flows during the past 20 years, but differently from similar economies, Indonesia began with a high volume of exports and imports, and has currently achieved a six-fold increase in the same time period, even though the intrazone trade "only" increased five-fold. APEC represents for Indonesia approximately, just like for the Philippines, around $80 \%$ of its total trade volumes.

Indonesia organized the APEC meetings back in 1994 and this, as we can notice in chart 9, came along with a significant 


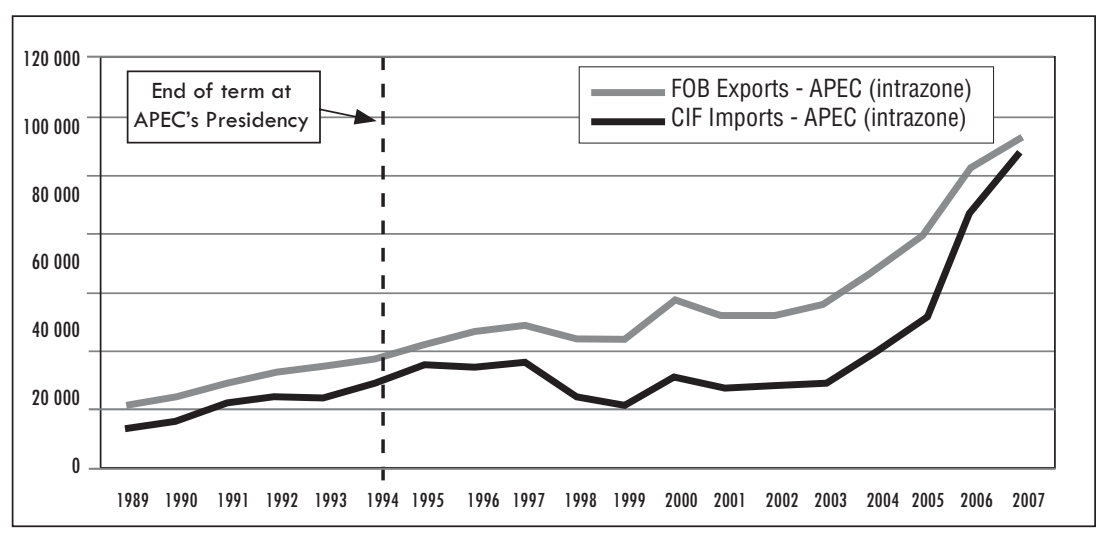

Source: IMF-DOT / Ministry of Finance of Taiwan / Trade Map.

Chart 9

Indonesia - Evolution of intrazone trade (1989-2007)

(In Millions of USD)

increase on its intrazone imports. Intrazone exports also grew, but they merely kept the growth trend that can be traced back to 1991 and extends to 1997 , when the exports decreased because of the Asian Crisis. This crisis also implied a backslide in the intrazone imports, a tendency that wouldn't be reverted until 2000. Exports registered a retrogress too, but their regression wasn't that steep. After a little fall in 2001, Indonesia's intrazone trade retook the growth path, but at an ever faster pace, especially on imports.

The main destination for Indonesian exports within APEC is Japan and, even though by the beginning of the 1990s this country bought over half of Indonesia's exports in the region, currently Japan only represents a quarter of this figure due to market diversification. Almost simultaneously, Indonesian exports have grown to both the U.S. and Singapore, which now comprise the same percentage of merchandise volume exported to the region (approximately $14 \%$ each). Other destinations that have also considerably increased their share are South Korea and China, especially after the latter entered AFTA.

On the importing side, Indonesia presented a much diversified array of suppliers during the second half of the 1990s and the first decade of the $21^{\text {st }}$ century, without a clear leadership among these suppliers for the intrazone imports. Just before 1998, Japan was Indonesia's main supplier, but then regressed due to the Asian Crisis. Since 2004 though, we can notice a high growth rate on imports from Singapore, which retook its leadership as Indonesia's main supplier, going from a $15 \%$ share to $35 \%$ in a generally favorable environment for exporting to Indonesia. China also had a strong presence as a supplier to Indonesia since 2003. Both China's and Singapore's participation increase could be attributed to an overall trade dynamism in the AFTA zone, since both countries could now export their goods to Indonesia once AFTA established trade preferences for them. 


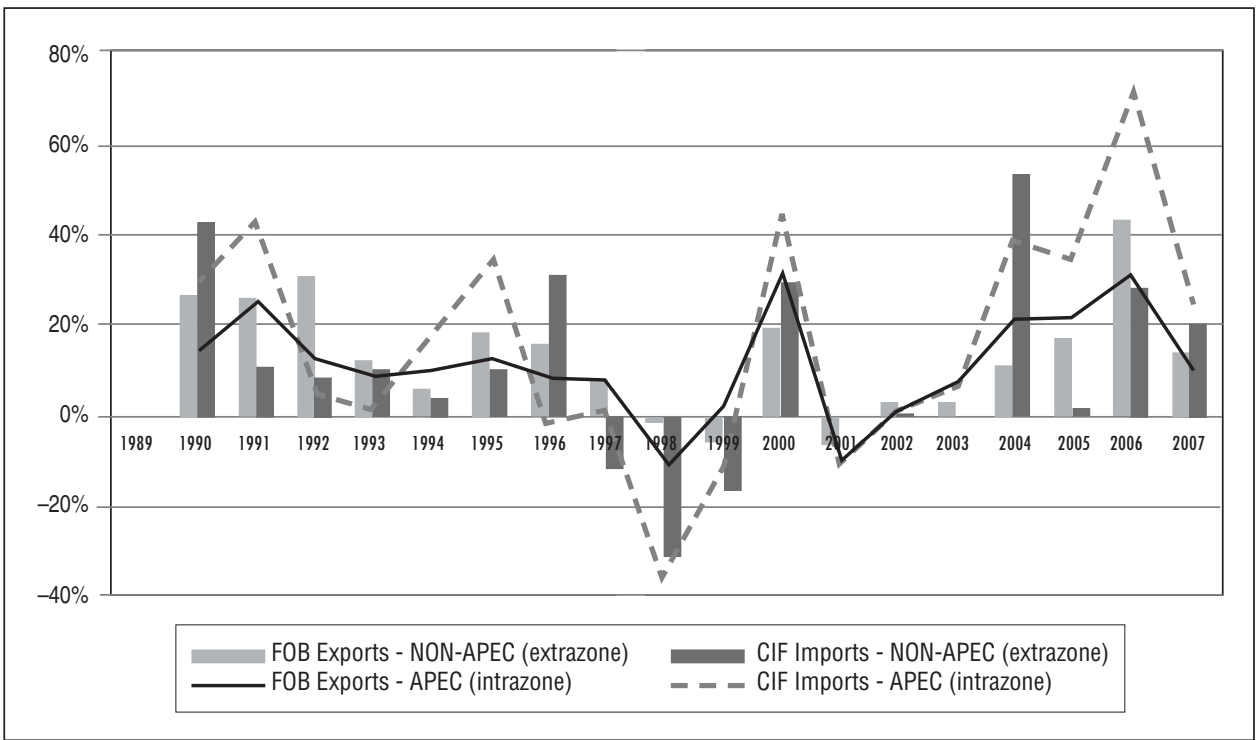

Source: IMF-DOT / Ministry of Finance of Taiwan / Trade Map.

Chart 10

Indonesia - Annual variation of intra and extrazone trade (1990-2007) (As a percentage)

Chart 10 shows that both intra and extrazone trade registered the same trends during the analyzed time period. When Indonesia assumed APEC's Presidency in 1994, we can note that intrazone imports fell sharply, aggravating the trend they already had, even though they entered a period of stagnation by 2006 . Likewise intrazone exports kept its sustained grow but to a lesser speed than those of the extrazone. We must indicate that in 1996, apparently extrazone imports substituted those from the intrazone; even so, Indonesian trade flows recovered during the first decade of the $21^{\text {st }}$ century.

\subsection{Malaysia}

Malaysia, Indonesia and Thailand are very similar when it comes to analyze their trade volumes and its intrazone growth rate.
Thus, Malaysia also presents a high intrazone trade growth rate, but more noticeably is the very similar amount of both exports and imports from 1989 to 1997; therefore, Malaysia trade balance with the rest of the APEC economies was virtually zero. Moreover, APEC represents for Malaysia nearly $75 \%$ of its total trade.

Malaysia assumed the Forum's Presidency in one of the most difficult times for the Asia-Pacific region: 1998, the year of the Asian Crisis. This fact explains the fall of Malaysian exports to and imports from the region, but surprisingly it wasn't as sharp as those of other Asian economies in APEC (see chart 11). Was it because of Malaysia's organizing APEC's meetings that year? This is an interesting question that requires further investigation. What we can certainly point out is that after the 


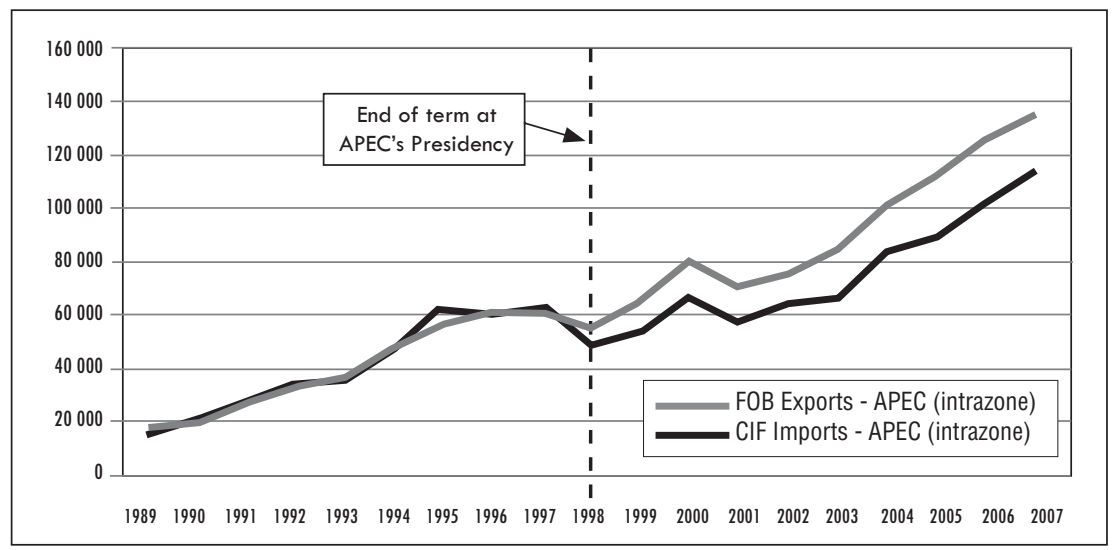

Source: IMF-DOT / Ministry of Finance of Taiwan / Trade Map.

\section{Chart 11}

Malaysia - Evolution of intrazone trade (1989-2007)

(In Millions of USD)

crisis (1999), Malaysian trade managed to recover though it isn't clearly whether it was because of Malaysia's hosting APEC summits or because of a statistical rebound ${ }^{7}$.

Malaysia's main export destinations in the Asia-Pacific region were the United States, Singapore and Japan, respectively. The share of the two first countries rounds $20 \%$ to $25 \%$ each out of Malaysia's intrazone exports, meanwhile Japan stands with a solid $14 \%$. This latter country signed a FTA with Malaysia in 2006, which allowed

7. According to Parodi (2001), even though the Asian Crisis "officially" began on July 2, 1997, with the "managed flotation" of Thailand's Baht as a measure to fight a strong speculative attack, the crisis showed its awful effects when foreign capital flew out of the region, Asian currencies plummeted and a strong contraction of the GDP of several Asian economies occurred. Nevertheless, the region demonstrated an astonishing ability to recover itself from such a disturbing event and by 1999 all economies had already surmounted the negative effects of the crisis. Especially remarkable was the recovery of South Korea (actually the first one to recover at all) and, on the contrary, Indonesia taken the longest time to recover. an increase in Malaysian exports to this destination. However, some other APEC economies have managed to raise their share on Malaysian's exports even faster than Japan which is progressively reducing the importance of Japan as a destination (just $11 \%$ by 2007). Just like some other Asian economies, Malaysia has seen a fastgrowing participation of new players in the region's trade, such as China, Hong Kong and Thailand. The growth of the share of the former is due to China's entering the AFTA, where Malaysian products now get tariff preferences for accessing the Chinese market.

When it comes to imports, Malaysia's main customers are, just like the other economies afore mentioned, its main suppliers: United States, Japan and Singapore together explain over $60 \%$ of Malaysia's imports during the 1990's. Malaysia began to diversify its intrazone imports since 2002 with a new player: China. The impact of the Chinese products in the composition of Malaysia's imports was such that China moved from having almost no products 
exported to Malaysia by 1990 , to become Malaysia's third most important supplier In the Asia-Pacific region with over USD 18 billions, even more that the U.S. and almost grasping the position of both Japan and Singapore. It's not surprising that the momentum attained by China's exports result in China grabbing the first place as a Malaysian supplier by 2008 or 2009.

In general terms, chart 12 shows that intra and extrazone trade present similar trends, except in 1998 when, due to the fall of intrazone exports, this were "diverted" to the extrazone countries, growing almost $10 \%$ that very year. Note that in 1999 , after Malaysia assumed APEC's Presidency, intra and extrazone trade grew, which reinforces the assumption of a "statistical rebound" that allowed to recover trade levels; furthermore, intrazone growth was slightly higher, probably because of the dynamism provoked by the APEC meetings. All in all, this recovery can apparently be attributed to several factors. Finally, it's worth mentioning that in the past few years, extrazone trade growth rates were higher than those of the intrazone, a factor that actually differentiates Malaysian trade from the rest of the Asian economies.

\subsection{Mexico}

The first Latin American country to join APEC was Mexico in 1993. Just like chart 13 shows, Mexican trade with the APEC countries has been very dynamic in the last 18 years. Within that time period, Mexican exports to the entire world increased eleven-fold, while those directed to APEC economies increased thirteen-fold. For imports, both to the world and to APEC

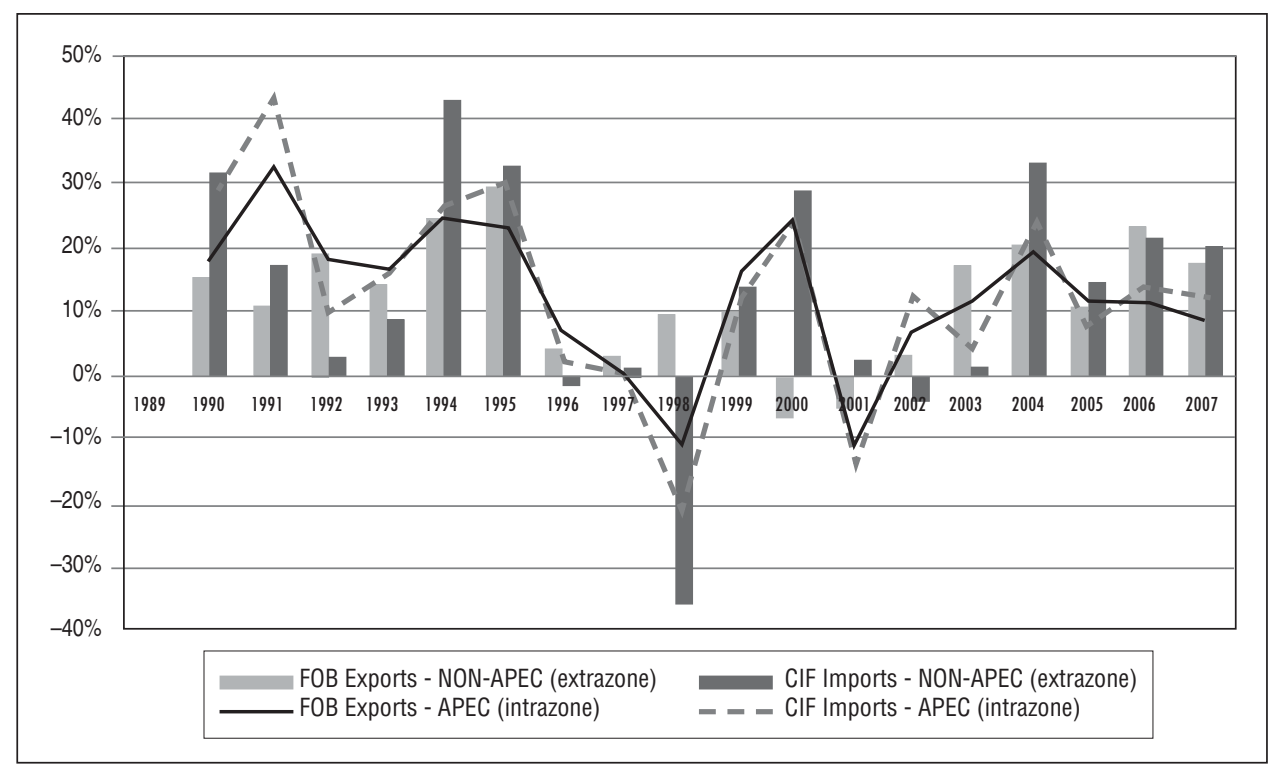

Source: IMF-DOT / Ministry of Finance of Taiwan / Trade Map.

Chart 12

Malaysia - Annual variation of intra and extrazone trade (1990-2007)

(As a percentage) 
economies, the increase was eleven-fold. However, the Mexican case requires a very special approach, since it's absolutely necessary to discriminate the "United States effect" to appropriately quantify the dynamism of its trade with the other APEC economies.

Accordingly, the United States alone explained, during the analyzed time frame, roughly $80 \%$ of all Mexican exports. This is definitely the result of NAFTA (1994) (see table 2), which made possible an average annual growth of Mexican exports to the U.S. of approximately $12,8 \%$, reaching an all-time record in 2007 with over USD 223 billions. Even though the figures for imports aren't as impressive as those for exports, it's important to say that, on average, Mexican imports from the U.S. account for $65 \%$ of global imports, registering also an all-time record in 2006 with USD 143 billions.

So, once we discriminate the effect of Mexican exports to the U.S., we can notice that the corresponding figure for merchan- dises sold to the rest of the Asia-Pacific region have risen up to USD 15 billions. However, these exports actually registered a higher growth rate by 2004 , with an average growth rate of $20 \%$ which lasted until 2007. Nonetheless, the biggest part of these exports is accounted by Canada (the other member of NAFTA) with an annual average $43,5 \%$ of all exports to the AsiaPacific region. The next main destination is Japan, a country which signed a FTA with Mexico in the second half of 2005. Even though this agreement is very important for Mexico, its exports to Japan haven't fully developed their potential, since recently China has risen as Mexico's second destination for its exports. It's also noticeably that for Mexico, Chile and Peru are significant markets that present an increasing share for total Mexican exports, a different situation from several Asian economies that also comprise APEC.

Figures change radically when looking at imports from the Asia-Pacific region. In this case, Mexico's main supplier in the region has been Japan until 2002, when

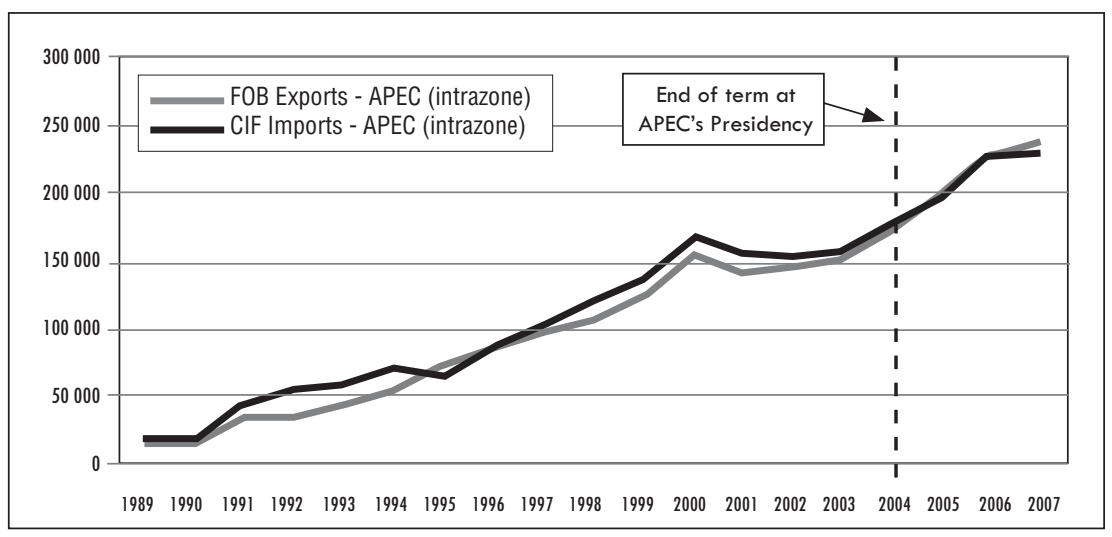

Source: IMF-DOT / Ministry of Finance of Taiwan / Trade Map / INEGI-BIE (Mexico).

\section{Chart 13}

Mexico - Evolution of intrazone trade (1989-2007)

(In Millions of USD) 
its leadership was taken over by China, which in turn became Mexico's second supplier just behind the United States. So, China, which began its explosive entrance in the Mexican market by 1995 with over USD 573 millions in exports, has reached an impressive USD 30 billions figure in exports to Mexico. After China and Japan, other important suppliers for Mexico are South Korea, Canada, Malaysia and Chinese Taipei, all of which register important growth rates in their exports to Mexico in the past 5 years. In fact, intrazone imports (excluding U.S.) are quite high: in 2007 an all-time record was set for Mexico, which in turn bought goods from the APEC economies for over USD 89 billions.

Now, regarding the impact of Mexico's assuming the Presidency of APEC in 2002, we can notice that its intrazone exports (excluding U.S.) surged with a $12 \%$ growth rate. Additionally, since 2004, there has been a sustained growth with an annual average rate of $24 \%$. Intrazone imports have also grown in 2002 by $17,5 \%$, but it was allegedly because of an already existing trend from the previous 6 years.

When analyzing the annual variation of both intra and extrazone trade of Mexico, chart 14 shows a big irregularity in both sides during the established time frame. Likewise, we can notice that intrazone exports apparently follow a totally different trend than intrazone imports. On the contrary, in the extrazone we can appreciate a higher coincidence between the indexes for buying and selling merchandises. In this chart intrazone exports (including U.S.), surged in 2002, but the rhythm fell afterwards to less than $10 \%$ annually for exports

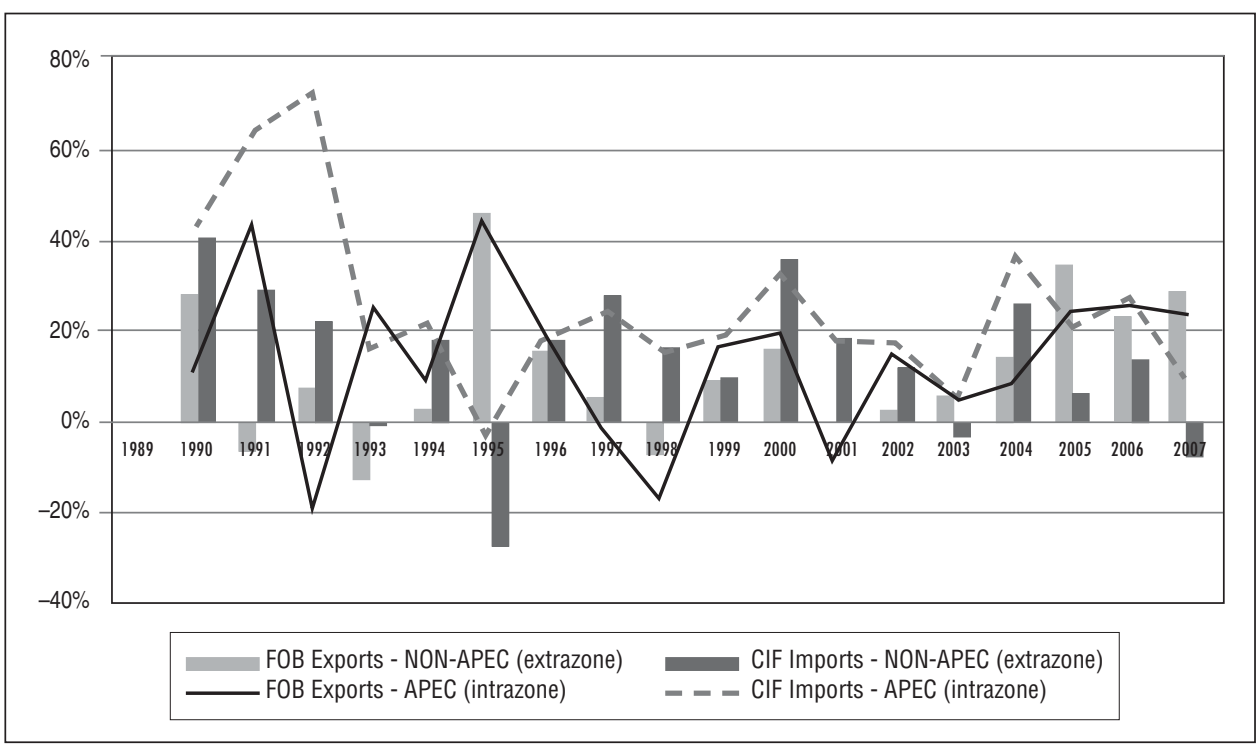

Source: IMF-DOT / Ministry of Finance of Taiwan / Trade Map / INEGI-BIE (Mexico).

\section{Chart 14}

Mexico - Annual variation of intra and extrazone trade (1990-2007)

(As a percentage) 
as well as for imports. This fall, however, was subverted by 2004 , then showing a sound growth of over $20 \%$ each following year. This recovery can also be noticed in the extrazone trade, extending to 2007.

\subsection{Thailand}

Thailand has been the only developing economy, as deemed in this document that has held the Forum's Presidency twice since its creation. Even though APEC economies have always been significant for Thailand, especially those located in Asia, their share in Thailand's trade has increased over the years. Thus, from representing a $60 \%$ weight in Thailand's exports in 1989 , APEC economies now account for $70 \%$. In contrast, the share of intrazone imports has nearly remained the same: approximately $68 \%$ of Thailand's global imports.

Just as chart 15 shows, and in a similar way to that of Indonesia and Malaysia,
Thailand has registered some very auspicious indicators in its trade relation with the rest of APEC economies. Furthermore, Thailand could actually subvert a deficit trade balance with the APEC economies and by 2007 it exports over USD 100 billions to the trade bloc.

A common point between the time periods after Thailand's assumption of APEC's Presidency was the sustainability or consolidation of its growth rates for intrazone trade. Accordingly, in 1993, after its first period as host country for APEC's meetings, both exports to and imports from the intrazone rose until 1996, where some stagnation was registered just before the Asian Crisis hit by 1998. Afterwards, Thai intrazone trade would show an astonishing recovery beginning in 2001, with a momentum that would keep up to date, comprising also its second period as host country.

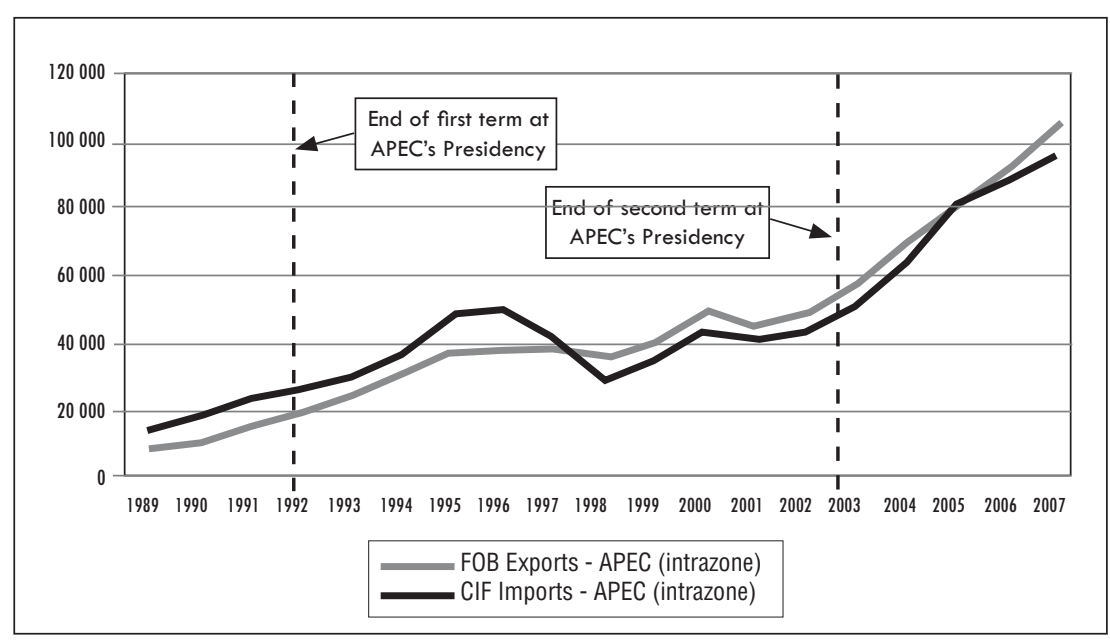

Source: IMF-DOT / Ministry of Finance of Taiwan / Trade Map.

\section{Chart 15}

Thailand - Evolution of intrazone trade (1989-2007)

(In Millions of USD) 
Traditionally, the main destinations for Thai exports in the Asia-Pacific region have been United States and Japan which by mid-1990's explained over 70\% of intrazone exports. This important share has been diminished in the last few years, reaching a low point of $35 \%$ (U.S. and Japan altogether) in 2007, favoring a stronger share for a new avid consumer of Thai products: China. Just in the same way that China has grown as an important customer for other Asian economies, Thailand has also seen its exports to China surge. In fact, Thai exports to China were almost none in 1990 but now represent over $14 \%$ of Thailand's total intrazone exports in 2007, accounting for over USD 14,8 billions. This momentum began in 2000 , but gained strength in 2003, when China joined AFTA.

Other important destinations for Thai exports were Singapore, Hong Kong and
Malaysia, which have increased their share in the last few years, just like some other APEC economies. It's remarkable that both Singapore and Malaysia are members of the AFTA, along with Thailand, since 1992, but their importance as export destinations is relatively recent.

On the importing side, Japan is Thailand's main supplier, even though is diminishing its share (once again) favoring other Asian economies. Thus, from representing over $50 \%$ of Thai imports from the region in 1989 , Japan only comprises $30 \%$ of these by 2007 . Something similar happened to United States, which had a share of over $20 \%$ in 1989 and now has half that figure. We must have in mind that both the U.S. and Japan have actually increased the total volume of goods exported to Thailand over these years, but other APEC economies have increased that volume even faster.

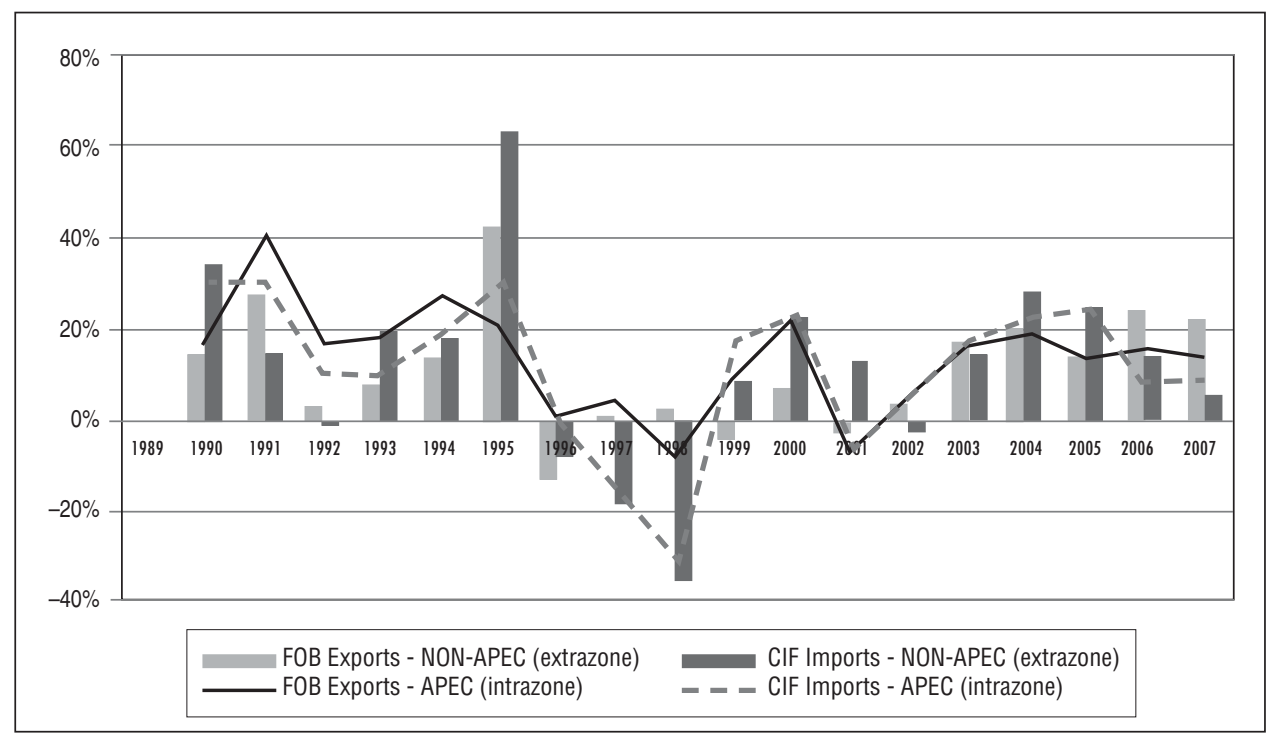

Source: IMF-DOT / Ministry of Finance of Taiwan / Trade Map.

Chart 16

Thailand - Annual variation of intra and extrazone trade (1990-2007)

(As a percentage) 
This is the case of China, which has now become Thailand's second supplier in recent years.

Chart 16 shows that in 1992, when Thailand first hosted the Forum's meetings, its exports to the intrazone registered a significant deceleration, just like those directed to the extrazone. Then Thailand thrived in sustaining their growth level which resulted in a noticeable increase two years later; imports registered a similar behavior. Afterward, when Thailand assumed the Presidency once again, we notice a slight acceleration in the growth rates the very next year (2004) of this commitment for intrazone trade. Nevertheless, these growth rates are similar to those registered for the extrazone. Finally, Thailand managed to sustain the growth of its exports to the intrazone in the last 3 years, but they don't grow as much as those directed to the extrazone.

\subsection{Vietnam}

The development of Vietnam's trade is perhaps the most impressive of all the developing economies in APEC: it went from USD 160 millions in exports to the Asia-Pacific region in 1987 to over USD 32 billions twenty years later. Even more impressive is the dynamism of Vietnam's imports from the intrazone: from USD 180 millions to over USD 52 billions in the same time frame. A curious fact rises when analyzing the evolution of Vietnamese trade: until 1990, the almost inexistent exports of this country were directed mainly to extrazone $(70 \%)$, however the very next year these exports made a radical change being directed now to the intrazone $(70 \%)$. Thus, the $70 \%$ of all Vietnamese exports are directed to APEC economies and this share has been sustained through the years. A similar situation happened on the importing side, with the sole difference that by 2007

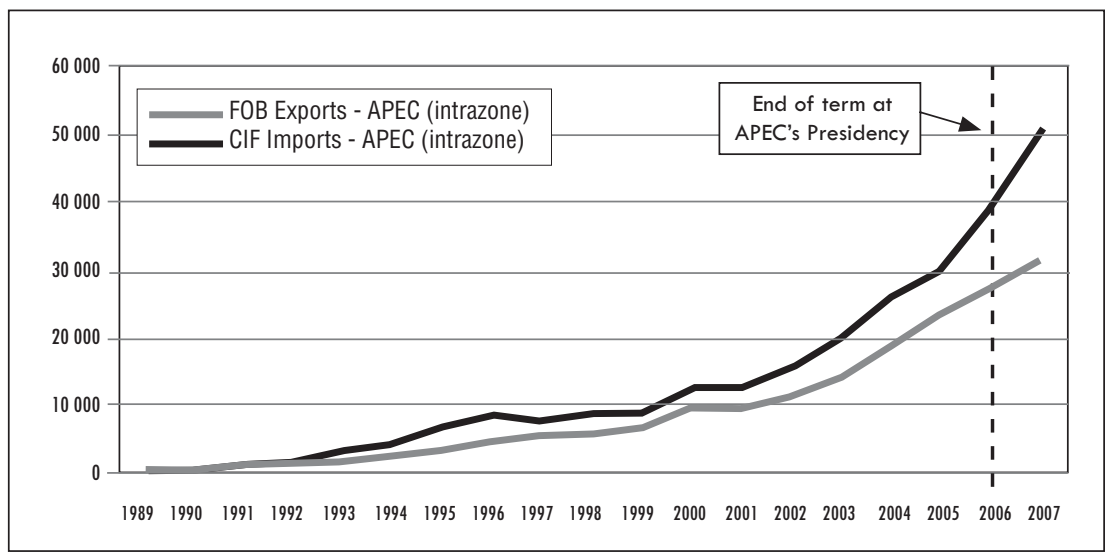

Source: IMF-DOT / Ministry of Finance of Taiwan / Trade Map.

Chart 17

Vietnam - Evolution of intrazone trade (1989-2007)

(In Millions of USD) 
intrazone imports represented over $85 \%$ of total Vietnamese imports.

Chart 17 shows how both Vietnamese imports from and exports to the intrazone increased after Vietnam assumed APEC's Presidency (2006). Admittedly, both of them already presented a previous growth trend, but imports actually accelerated considerably, meanwhile the export's acceleration was merely marginal.

Japan and Singapore have usually been Vietnam's main destinations for its exports. Nonetheless, in 1995 Vietnam started to diversify its export markets and by 1999 they were highly diversified. That same year, the United States became a customer for Vietnamese exporters and quickly grabbed the label as Vietnam's main destination. In fact, by 2007 the U.S. explains more than $30 \%$ of Vietnam's exports to the intrazone (with over USD 10 billions) and is Vietnam's main trading partner. Japan is second in the ranking, just above Australia, which only appears in Vietnam as one of the top three destinations for exports of an APEC developing economy. China is also important for Vietnamese exports $\left(4^{\text {th }}\right.$ place in the ranking) but doesn't have a significant growth rate as a buyer of Vietnamese goods.

On the imports side, Vietnam buys products mainly from Japan and Singapore. Just like other economies analyzed in this document, since 2000 Chinese exports to Vietnam surged and quickly grabbed the first place of preference for Vietnamese importers (2003); this fact was reinforced by China's joining AFTA. However, China hasn't been the only surprise when exam-

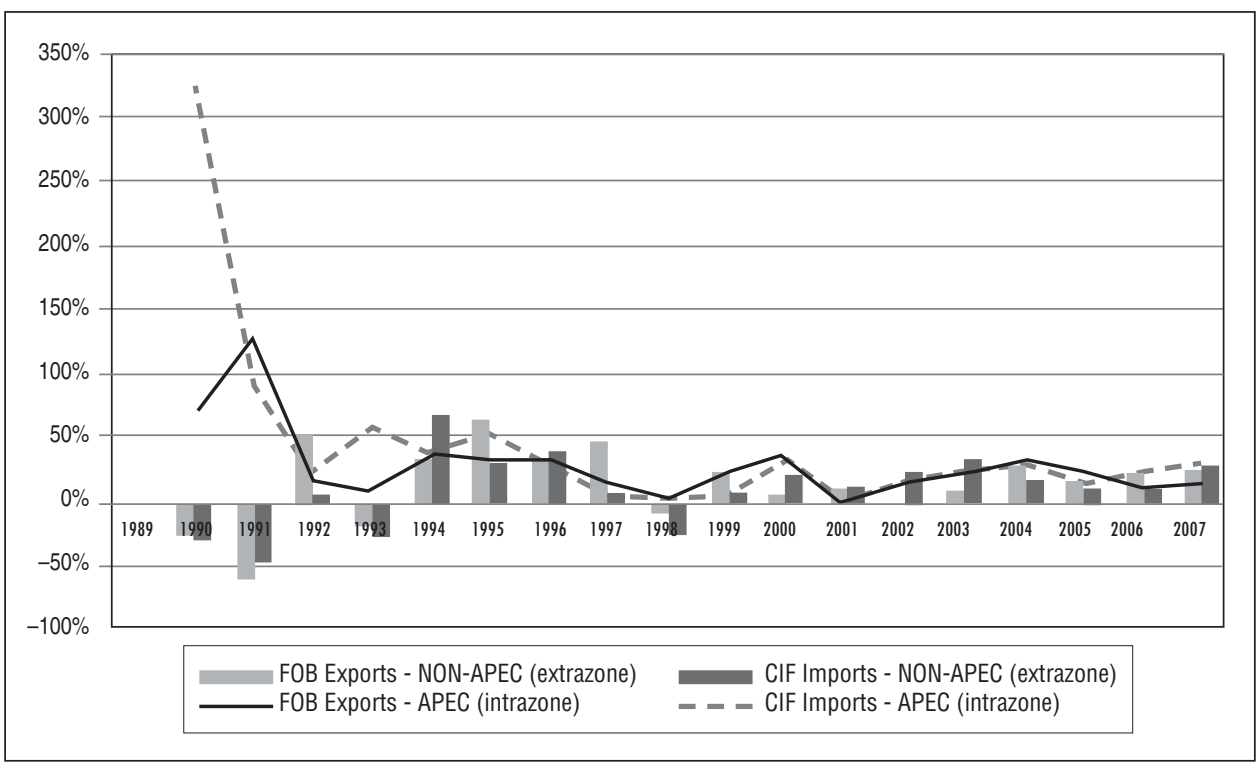

Source: IMF-DOT / Ministry of Finance of Taiwan / Trade Map.

Chart 18

Vietnam - Annual variation of intra and extrazone trade (1990-2007)

(As a percentage) 
ining Vietnam's main suppliers: in the last few years, there's a strong growth in the share of South Korea, Chinese Taipei and Thailand, respectively.

Chart 18 presents how Vietnam's trade with the APEC economies acquired a strong momentum by the early 1990's. Even though this could be attributed to the exiguous trade flows registered before that time, we can notice there was a rearrangement of Vietnam's trading partners, since extrazone trade reduced during this time. Even so, Vietnam's trade relations with both the intra and extrazone would keep the same trend since 1994. It's worth mentioning that when Vietnam joined APEC (1998, the year of the Asian Crisis), allegedly its entrance contributed to the dynamism of intrazone trade afterwards, which in time allowed several economies to forego the trade stagnation registered that year. Finally, we must point out that Vietnam's intrazone trade after assuming the Forum's Presidency didn't register a significant acceleration compared to previous years.

\subsection{Comparison of intrazone trade in selected developing economies}

After analyzing each case individually, it's convenient to compare what happened to APEC's developing economies right after assuming the Forum's Presidency, in terms of variation of their growth rates for intrazone trade. In first place, let's take a look at chart 19; we can notice that Chile registers the highest growth rates in exports as in imports, immediately after assuming that commitment. We can also notice that half of the cases presented a higher growth rate for exports as for imports.

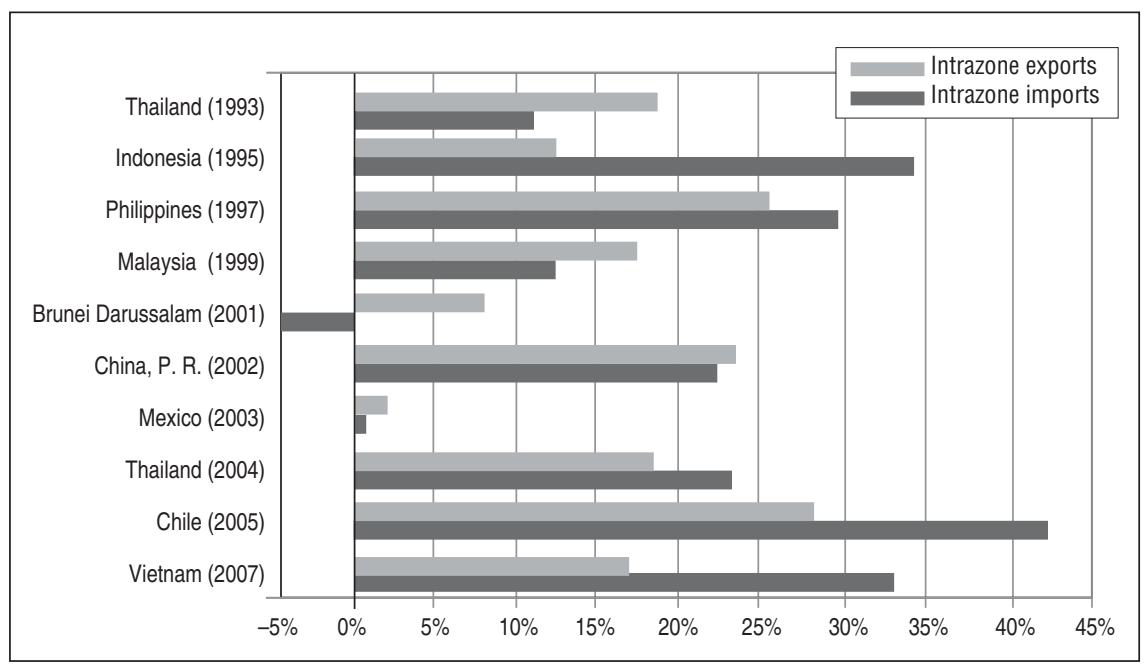

Source: IMF-DOT / Ministry of Finance of Taiwan / Trade Map.

Chart 19

Growth for intrazone trade for selected economies, the year after they assumed APEC's Presidency

(As a percentage) 
It's important, however, to observer which has been the level of acceleration of the growth rates for intrazone trade; this will allow us to determine whether this variation is the result of a previous trend. So, when observing the trends intrazone exports for the selected developing economies the very next year they assumed APEC's Presidency, we can notice that three of them (Brunei Darussalam, Indonesia and Vietnam) presented virtually no significant variation or acceleration; therefore, they kept their existing growth trend. Three other economies (Chile, Mexico and Thailand, during its first term), suffered a deceleration in their growth trends for intrazone exports. Finally, four economies (China, Philippines, Malaysia and Thailand, during its second term) effectively accelerated their growth rates for intrazone exports.

As for growth for intrazone imports the year after assuming the Forum's Presidency, only Vietnam didn't show a significant acceleration nor deceleration considering the previous years. Three economies (Brunei, Mexico and Thailand, during its first term) saw a deceleration of their intrazone imports. Meanwhile, six economies (Chile, China, Philippines, Indonesia, Malaysia and Thailand, during its second term) presented acceleration, often quite significant, in their growth rates for intrazone imports.

Finally, it's important to evaluate the growth performance in the long run for intrazone trade for these developing economies. Even though the time series is relatively short to properly evaluate every single selected economy, it's possible to notice that growth rates after assuming APEC's Presidency are sustained only for half of the cases, so there's some regular growth in half of the observations. Furthermore, regular or sustained growth rates in intrazone exports, usually go accompanied by sustained growth rates in intrazone imports.

\section{Analysis of attraction of foreign direct investment from the Asia-Pacific region: The experience of Latin America}

In contrast to trade data availability, those of foreign direct investment (FDI) are usually very disperse and often register inconsistencies, due to the varying methodologies used in their gathering and processing. Moreover, the frequent usage of national currencies to present information (without specifying if data is in current or constant rates) increases the difficulty to find accurate time series. Therefore, and since one of the objectives of the present working paper is to offer accurate information that allows to generate discussion on the impact that could have for a developing economy the assumption of APEC's Presidency, we only have reliable data for Mexico and Chile, which hosted the summits in 2002 and 2004 respectively ${ }^{8}$. As we mentioned in the introduction, FDI, thanks to the multiple economic and non-economic benefits it generates, is capable to make a big contribution to reduce poverty in developing economies. Several socioeconomic indicators in many developing economies have registered a substantial growth as a result of a sound policy for FDI attraction (creating a favorable environment for investment), especially in some APEC economies (World Bank, 2002). In all, we

8. Future analyses, however, should focus on evaluating FDI in the rest of APEC's developing economies that have assumed its Presidency. 
can definitely affirm that FDI stimulates economic growth (World Bank, 2001).

Despite the lack of standardized information, some recent efforts have had a focus on analyzing the performance of FDI in the Asia-Pacific region. In fact, both Nixon (2007) and APEC Investment Experts Group or AIEG (2007) agree that developing economies in the APEC region are registering increasing levels of investment, which is quite positive since nearly all APEC economies present already high levels of investment. However, FDI represents only $5 \%$ of the global investment amounts registered by APEC economies, while over three fourths of total investment is merely domestic. After reaching a peak of almost USD 600 billions in 2000, FDI inflows in APEC have fallen to nearly USD 300 billions in 2005 . Nevertheless, both Nixon and AIEG agree that FDI inflows are not uniform within
APEC. Obviously, United States and China attracted most of the FDI in the region; at the same time, United States, Japan and Canada were the origin of FDI outflows. AIEG found that, according to empiric evidence and economic theory, FDI flows from developed to developing economies, registered the largest amounts. Another important conclusion by AIEG (2007) is that almost $40 \%$ of FDI inflows to APEC economies come from fellow APEC economies. In general terms, developing economies worldwide are registering a significant increase in their FDI inflows. Financial Times' FDI Magazine states that developing countries attracted over USD 256 billions on FDI inflows in 2007, setting an all-time record both in volume and growth (115\% compared to 2006). Furthermore, according to the OCO Global Ltd. (a consulting firm specialized on FDI), the Asia-Pacific region leads the attraction of FDI with over USD

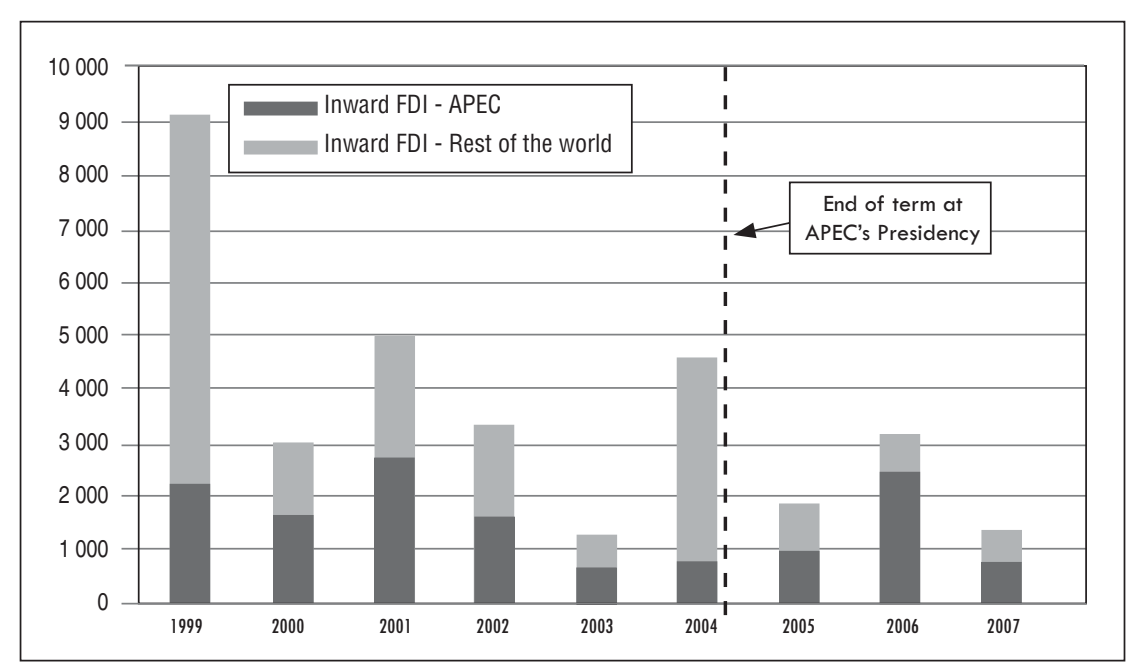

Source: Chilean Committee of Foreign Investments.

Chart 20

Chile - Evolution of FDI inflows (1999-2007)

(In Millions of USD) 
395 billions in 2007, which means a $20 \%$ growth compared with the previous year.

\subsection{Chile}

Chart 20 shows the evolution of FDI inflows in Chile from 1999 to 2007. It's important to notice that according to AIEG (2007), Chile is APEC's main net importer of FDI according to the size of its economy; thus, the volume of annual FDI inflows in Chine equals, on average, $4 \%$ of its GDP. Now, when evaluating the growth of FDI inflows originated in other APEC economies, we can notice that growth turned to be irregular, with an average growth of $4 \%$. In contrast, FDI inflows from non-APEC countries are also irregular, but present an average growth rate of $50 \%$ for the time period in analysis. However, it's remarkable that after Chile assumed APEC's Presidency (2004), most of Chile's FDI inflows came from the APEC region, comprising over Chile's $64 \%$ of global investment.

Regarding the origin of FDI suppliers to Chile within APEC, we can notice that both United States and Canada are the most important exporters of capital to Chile, each with a $36 \%$ annual share from intrazone FDI inflows. FDI coming from the rest of the world is mainly from Spain, the United Kingdom and Italy.

\subsection{Mexico}

Just like trade, the case of Mexico is quite particular, since United States has historically represented over $70 \%$ of annual FDI inflows in this country, even though this share has decreased in the last few years as a result of more diversified array of investing countries. Chart 21 presents its evolution; therefore, during the established

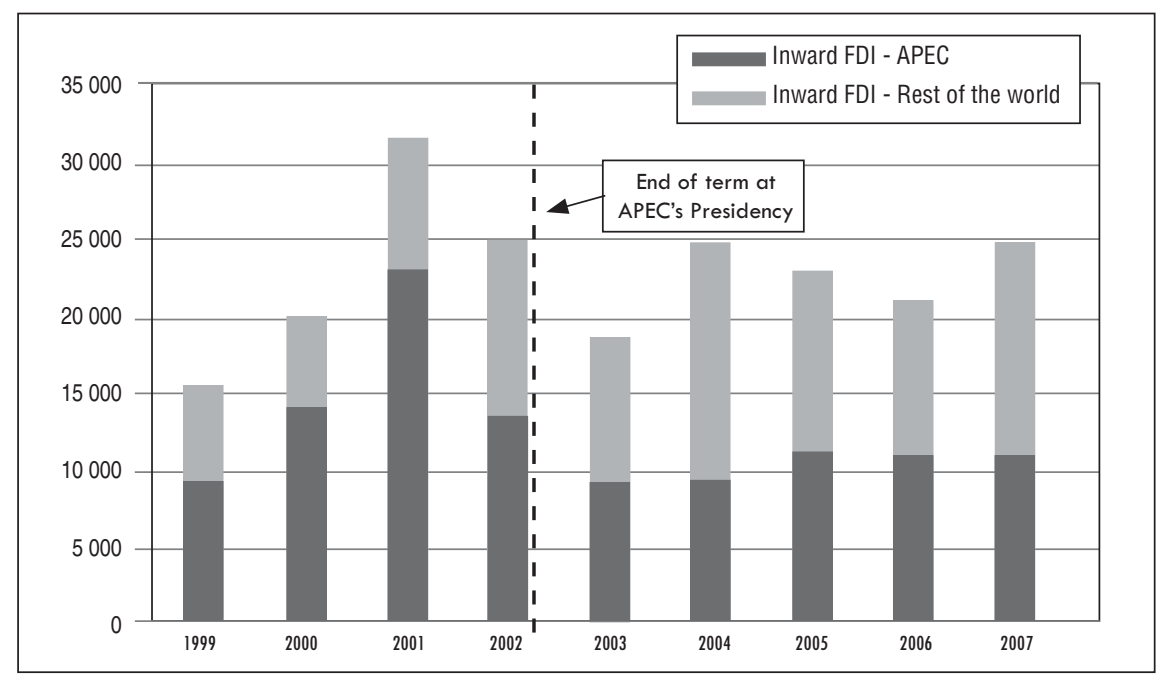

Source: General Directorate of Foreign Investment-Secretariat of Economy of Mexico.

Chart 21

Mexico - Evolution of FDI inflows (1999-2007)

(In Millions of USD) 
time frame, APEC has represented, on average, $55 \%$ of total FDI inflows into Mexico, but United States alone comprises $92 \%$ of this amount. The rest of FDI inflows from APEC are quite irregular, even registering a negative growth rate of FDI inflows.

As a conclusion, we can notice that after Mexico assumed APEC's Presidency, FDI inflows in Mexico somehow stabilized in roughly USD 10 billions annually. Even though this figure didn't present a significant growth in the following years, it is definitely an important amount of attracted FDI. Besides United States, other important APEC investors in Mexico are Canada, Japan, South Korea and Australia.

\section{Concluding remarks}

As we can notice throughout this document, developing economies in APEC have shown a strong growth pace in trade, both intrazone and extrazone. Exports and imports have presented a quite high dynamism, even though their growth was seriously affected by the Asian Crisis of 1998. Fortunately, growth rates recovered by 1999 , a trend that keeps up to the present date.

Whether is valid to presume that assuming APEC's Presidency allows any of its member economies to foster business with the Asia-Pacific region, in light of empiric evidence, it isn't possible to soundly affirm that this mere fact automatically grants an exports increase. Even though all developing economies that have assumed the Presidency have registered some degree of growth in their exports, at least during the very next year of this commitment, less than half of the cases analyzed present an effective acceleration in their growth rates. In some cases, the acceleration of growth in exports could be attributed to the entry into force of some FTA or to the overall situation of the global economy (an improvement in the terms of trade or the ending of a regional crisis, for example).

In contrast, is on the imports side that we find more coincidences: for the analyzed economies, the majority of them presented acceleration in the growth rates of their imports from the Asia-Pacific region. Do business meetings, both formal and informal, originated within the APEC summits in a developing economy, create a bigger awareness in the host country about the existence of interesting import opportunities from the region? This question could be answered with further studies that evaluate the import structure with all trade partners right after the developing economy has hosted all of APEC meetings.

Moreover, as we stated in the end of section 1, being host of APEC summits wouldn't guarantee the sustainability of growth rates in trade with the region. Admittedly, there are several factors that must be considered in order to guarantee a sustained growth in this aspect.

Regarding the attraction of FDI from the Asia-Pacific region, it's even less feasible to establish any generalization, since the information is too disperse and lacks of homogenized criteria for its compiling to be properly evaluated. Nevertheless, the case of Chile deserves to be underscored due to its interesting growth rates of FDI inflows from fellow APEC economies right after it hosted the Forum's summits. Future studies should take into account a thorough data compilation for the rest of developing economies that may lead to 
conclusions based in a greater number of observations.

Finally, even though trade growth and FDI attraction from other APEC economies wouldn't depend exclusively in holding
APEC's Presidency, this commitment is without a doubt extremely transcendent for a developing economy since it is a unique opportunity to massively promote business with the world's most important economic bloc.

\section{References}

\section{ASIA PACIFIC ECONOMIC COOPERATION} FORUM. 2008. APEC at a glance. Singapore: APEC Secretariat.

APEC Investment Experts Group. 2007. Guide to the Investment Regimes of the APEC Member Economies-2007. $6^{\text {a }}$ ed. Singapore: APEC Secretariat.

BHAGWATI, Jagdish. 2007. In Defense of Globalization. $2^{\text {a }}$ ed. New York: Oxford University Press.

CHAN, Julio. 2008. APEC y el Perú: Guía sobre el foro de Cooperación Económica Asia-Pacífico y la participación del Perú. Lima: Universidad de Lima.

\section{DEPARTMENT OF FOREIGN AFFAIRS AND} TRADE, Australia. 2006. The APEC Region Trade and Investment 2006. Canberra: Commonwealth of Australia.

2007. The APEC Region Trade and Investment 2007. Canberra: Commonwealth of Australia.

DOLLAR, David and KRAAY, Art. 2001. Trade, Growth, and Poverty. Washington D.C.: Development Research Group, The World Bank.

FDI MAGAZINE. 2008. FDI increases in developing world (consulted on Jun. 6, 2008). <http://www.fdimagazine.com/news/ fullstory.php/aid/2347/FDI_increases_in developing_world.html>.
INTERNATIONAL MONETARY FUND (IMF). 2008. World Economic OutlookApril 08: Housing and the business cycle. Washington D.C.: IMF.

GOLDIN, Ian and REINERT, Kenneth. 2006. Globalización para el desarrollo: Comercio, financiación, ayuda, migración y politicas. Bogotá: Planeta-BIRF-BM.

GONZÁLEZ-VIGIL, Fernando (ed.) 2006. Tópicos de negociaciones comerciales internacionales: metodologías y aplicaciones relevantes para el Perú. Lima: Universidad del Pacífico.

KRUGMAN, Paul and OBSTFELD, Maurice. 2006. International Economics: Theory and policy. $7^{\mathrm{a}}$ ed. Boston: Pearson-Addison, Wesley \& Longman.

NIXON, Roy. 2007. Improving the investment climate in APEC economies. Canberra: The Australian Commonwealth Treasury.

OCO GLOBAL LTD. 2008. Global Foreign Direct Investment grows to almost US\$ 1 trillion in 2007 (consulted on Jun. 6, 2008). $<$ http://www.ocoglobal.com/files/news/ oco_us_press_release_040308.pdf>.

ORGANIZATION FOR ECONOMIC COOPERATION AND DEVELOPMENT (OECD). 1999. Open markets matter: the benefits of trade and investment liberalization. In OECD. 1999. Observer Policy Brief. Oct. Paris: OECD. 
PARODI, Carlos. 2001. Globalización y crisis financieras internacionales. Lima: Universidad del Pacífico-Centro de Investigación.

RUMBAUGH, Thomas and BLANCHER, Nicolas. 2004. China: International Trade and WTO Accession. Washington D.C.: IMF Working Paper.

SCHIFF, Maurice and WINTERS, L. Alan. 2003. Regional integration and development. Washington D.C.: The International Bank for Reconstruction and DevelopmentThe World Bank-Oxford University Press.

SOLOAGA, Isidro and WINTERS, L. Alan. 2001. Regionalism in the Nineties: What effect on trade? Washington D.C.: The World Bank.

UNITED NATIONS CONFERENCE FOR TRADEAND DEVELOPMENT(UNCTAD). 2006. Handbook of Statistics 2006-2007. Geneva: The United Nations Publishing.
2007. World Investment Report 2007. Geneva: The United Nations Publishing.

WORLD BANK. 2001. Global Economic Prospects 2002 and the Developing Countries. Washington D.C.: The International Bank for Reconstruction and Development-The World Bank.

2002. A case for aid: Building a consensus for development assistance. Washington D.C.: The International Bank for Reconstruction and Development-The World Bank.

2004. Global Economic Prospects 2005: Trade, Regionalism, and Development. Washington D.C.: The International Bank for Reconstruction and Development-The World Bank.

WORLD TRADE ORGANIZATION (WTO). 2008. World trade in 2007 and perspectives for 2008. Press release. Geneva: WTO. 
